\title{
Yeni Bir Yaklaşım Önerisi: Katmanlaşma Teorisi Bağlamında Yemeğin Sosyolojik İzdüşümleri (Karabük Örneği)
}

\author{
Adem Sağır' ${ }^{1}$
}

\section{Öz}

Bu çalışmada yemek kültürünün özgünlüğünü korumaya çalışan biçimlerini içermesi bakımından araştırmacı tarafindan sistematize edilmiş "katmanlaşma yaklaşımı" kullanılmıştır. Katmanlar yöresel, bölgesel ve fastfood mutfak şeklinde üç temel kategori olarak belirlenmiştir. Çalışma nitel prosedürler ile yürütülmüştür. Bu doğrultuda yarı yapılandırılmış görüşme, gözlem ve literatür incelemesi yapılmıştı. Çalışmada amaçlı örneklem kriterine göre hareket edilmiş, maksimum çeşitlilik örneklemesi tercih edilerek üç farklı grup üzerinden 28 kişi ile görüşülmüştür. Araştrrmada yemeğin kültürel bellekle kurduğu ilişkinin nasıl ve hangi araçlarla gerçekleştiği, yemekle aidiyetlik geliştirilirken kişiye hangi anlamlandırmaların eşlik ettiği, mekânın yemeği dönüştürmesinde hangi görünümlerin ortaya çıktığının sorgulanması ana sorunsallar olarak tasarlanmıştı. Çalışmada yöresel mutfağın turistikleşirken özgünlüğünü kaybettiği, bölgesel mutfaklarla karşılaştı̆ında ise yeni sentezler ortaya çıkarttğı tespit edilmiştir. Turistik yerlerdeki yemeklerin gittikçe birbirine benzediği ve tarihsel köklerini kaybettiği tespiti çalışmada McÇinlileşme olarak tanımlanmıştır. Bölgesel mutfakta ortaya çıkan sentez görünümler, standartlaşmanın temel uzantısı olarak değerlendirilmiş ve mekânı yöreselin de içerisinde sergilendiği otantik bir müzeye dönüştürdüğüne vurgu yapılmıştır. Fastfood mutfak küreselleşmenin ve üniversitenin şehirde yarattğı değişimlerle ilişkilendirilmiştir. Bu bağlam geleneksel yemek mekânlarının parçalandığı ve yemek etrafindaki ilişkilerin değiştiği sonucunu ortaya çıkarmıştı. Yabancı uyruklu öğrencilerin şehirde yarattğı değişimler ise onlara dönük açılan mekânların varlı̆ı̆na yapılan vurguyla betimlenmiştir. Çalışma yöresel, bölgesel, ulusal ve küresel mutfak pratiklerinin içe içe geçen biçimlerini "katmanlaşma yaklaşımıyla" gündeme getirmesi bağlamında ve yeni bir perspektif sunma iddiasını taşıması bakımından özgündür.

Anahtar Kelimeler: Kültür • Kimlik • Yemek • Katmanlaşma • Karabük

A New Approach Proposal: Sociological Projections of Food in the Context of Stratification Theory (Karabük Case)

\section{Abstract}

In this study, "Stratification Approach" which was systematized by the resesrcher was used as it includes the forms which try to protect the specificity of food culture. The stratums were determined in three main categories as "refional cuisine", "local cuisine" and "fastfood cuisine". The categories were made with the consideration that a new approach form is presented to the literature of food sociology. This study was conducted with the qualitative procedure. Accordingly, the semi-structured interview, observation and literature review were made as the method of data collection. It was conducted by the criteria of purposive sampling in the study, and it was structured with the data of interviews which were made with 28 persons in three different groups as the maximum diversification sampling was preferred. In the research, it was designed as the main problematics to query about how the relationship that the food has with the cultural memory occurs and what vehicles it occurs with, what interpretations accompanies with the person while developing the relationship with the food, what the views come in as the place transforms the food. In the study, it was determined that the regional cuisine gets lost its specificity while being touristic and reveals the new syntheses when it is compared with the local cuisines. In the study that the foods in the touristic places gradually resembled each other, and it got lost its historical roots, it was defined as Mc-Being Chinese. The synthesis views which occur in the local cuisine were evaluated as the main extension of standardization and it was emphasized that it transforms the place into an authentic museum where the regional one is exhibited. In the fastfood cuisine stratum, it was associated with the changings that the globalization and university create in the city. This context reveals the result that the traditional food places disintegrate and the relationships around the food change. The changings that foreignnational university students created in the city were described with emphasis on the existence of places where were opened for them. The study is a distinctive one because it revives the telescopic forms of regional, local, national and global cuisine practices through "the stratification approach, and as it has a suggestion to present a new perspective.

Keywords: Culture $\bullet$ Identity $\bullet$ Food $\bullet$ Stratification $\bullet$ Karabük

1 Adem Sağır (Doç. Dr.), Karabük Üniversitesi, Edebiyat Fakültesi, Sosyoloji Bölümü, Karabük, Türkiye.

Eposta: ademsagir@karabuk.edu.tr ORCID: 0000-0003-0763-0518

Att: Sağır, A. (2020). Yeni bir yaklaşım önerisi: Katmanlaşma teorisi bağlamında yemeğin sosyolojik izdüşümleri (Karabük örneği). İstanbul Üniversitesi Sosyoloji Dergisi, 40, 309-338. https://doi.org/10.26650/SJ.2020.40.1.0023 


\section{Extended Summary}

When choice occurs in discussions about food and nourishment, researching this topic these days is specifically more remarkable. This choice is directly related to how people have changed their food habits during the \#stayinghome period of the Corona virus. These discussions are accompanied by many subheadings such as reorganizing restaurants, no longer having fast-food because of malls being closed, cooking at home, and gardening on the balcony or in the yard. Because nourishment is a basic need for humankind, food and meals will always remain on the agenda. In fact, food is being experienced as a significant daily routine during this pandemic. This experience reminded people of food's sociological roots. However food has been highlighted in the framework of the consumption industry as something to be bought and sold. Materialism is a matter of objectivism and tells the story of how a public phenomenon has lost its historical and cultural roots. Consumer society expects to turn everything into a consumable material and for everyone to yield to this progress. Ritzer (2019) highlighted the effects of having McDonalds everywhere. The current study covers discussions about identity, culture, and belonging through the pressure arising from local, regional, and national cuisines.

This study uses the layered approach as a new approach for understanding and interpreting all kinds of changes about cuisine. This approach categorizes public experiences of a certain cuisine under three different branches: local, regional, and fast-food. Although no acute differences exist among these, local cuisine is used to refer to the food routines from a certain region of a certain country. Regional cuisine is considered as a modern interpretation of food experiences that have rare relations with historical food routines. Fast-food, on the other hand, is used to describe the changes of food routines in terms of time, place, and relations. Thus, local cuisine describes localization and genuineness, regional cuisine describes national dimensions, and fast-food represents global fields. Cognitive organizational constructions (Scheme 1) have been used to refer to corrupted relations between a society and its cultural roots. Typical perspectives of each stratum are effective at classifying these preferences. Within the layered approach, the common point of these three experiences is their individual aspects as opposed to their cultural or identical ones. Belonging, nationalism, globalism, retention, and localism represent the common experiences different cuisines have. Through this study, what common point of experience the layers approach has been highlighted as the cake-like taste transition between layers. These telescopic points the discussants mentioned in relation to food also legitimatize this highlight. Whether this experience takes place as a micro -or macro- change is related to the geographical area the society chooses or where the area is located. Experiencing these inter-layers occurs through parallel connections. The concept of "immigrant" is overly emphasized for this reason because immigrants try to protect their own cuisines while simultaneously getting used to the new cuisine of their new society, which results in 
bringing these cuisines together to find new routines. Localness is used to describe the experience of becoming anonymous in the face of globalization while trying to protect genuineness. Fast food, on the other hand, is used to describe how genuineness becomes global and how something global becomes local.

Discussing the significant points that frame the layered approach has been possible in Karabük. Safranbolu grounds the claims of genuine and local cuisine using cultural transitions. However, during this research, the traditional food routines are clarified as having been lost in Safranbolu. The menus of restaurants and cafes that have "local" in their name are mostly preferred by tourists rather than the genuine locals. McDonaldization expresses the idea that cuisines have lost their genuineness/originality and have become almost the same everywhere. During this process, having food yield to being anonymous and global is very important.

Within this study, regional cuisine has been determined to be a synthesis of cuisines. This study has addresses expanding the locales of food, changing its originality, and having different cuisines, and has also determined that fast-food changed places with traditional cuisine through public relations. In addition, international students attending Karabük University from different countries deal with the situation from another perspective. Increased pressure over cafes and restaurants has caused new places to open that address refugee students. Thus different national cuisines have been welcomed in Karabük for the very first time. This study presents that layers must gradually be studied through more sub-dimensions. By having a picture of different experiences through new layers, the originality of the layered approach is emphasized. 


\section{Yeni Bir Yaklaşım Önerisi: Katmanlaşma Teorisi Bağlamında Yemeğin Sosyolojik İzdüşümleri (Karabük Örneği)}

\section{Giriş Yerine: Yemeğin Sosyolojisini Yapmak}

Küreselleşmenin hızlandırdığı bir dünyada iç içe geçmiş yapılara karşı direnç, homojenlik içerisinde yerel kalabilmenin ne kadar sağlanabildiğiyle ilişkili hale gelmiştir. Bu ilişkisellik, yerele ait olan her türlü unsuru bir direniş aracına dönüştürmekte ve kimliklerin sürdürülebilirliğine katkı sunmaktadır. Yerel kültüre ait unsurlar ise farklılıklarını göstergeleştirdiği, sembolleştirdiği ve süreç içerisinde yeniden inşa ettiği sürece anlamlı kalmaktadır. Ancak teknolojik gelişmelerin küresel dönüşümlere akışkanlık kazandırdığı günümüz dünyasında toplulukları tanımlayıcı yerel unsurlara ulaşmak da gittikçe güç olmaktadır. Kültürel geçmişin unutulması, aynı zamanda belleğin de ciddi anlamda kayba uğraması anlamına gelmektedir. Böylece gündelik hayatın akışkanlığı, belleğin depolayıcı, saklayıcı ve kuşaklararası bağlantıları sağlayıcı yönünü de (Halbwachs, 2017) aşındırmaktadır. Belleğin küresel kültür karşısındaki konumlanma biçimi de bu tartışma için önemlidir. Küresel kültür, herkesin ne yapması gerektiği sorusuna önceden verilen yanıtları içermesinden ziyade, topluluklara baskı kurması nedeniyle dikkate değerdir. Küresel kültürün bu yönü bireyleri herkes gibi davranmaya zorlayan bir durumu ifade etmektedir. Kuşkusuz burada aslolan belleğin sürdürülmesinde hangi toplumsal süreçlerin ortaya çıtığ 1 ve hangi faktörlerin etkili olduğudur. Çalışmaya konu olması bakımından “yemek” olgusu da bu direnç noktalarının başında yer alan toplumsal bir gerçekliktir.

Yemek ve mutfak kültürü, bir karın doyurma eyleminden çok daha fazlasını içermektedir. Kültürel belleği ve kimliği yaşatan, akışkan dünyada (Bauman, 2019) topluluklara güvenlikli bir koza (Giddens, 2019) sağlayan yemek ve mutfak kültürü, yemeğe ait bütün unsurların aslında kimliğin kurucu ve tanımlayıcı bileşenlerini ortaya çıkartması bakımından da önemlidir (Beşirli, 2010; Beşirli, 2011). Yemek, kültür ve kimlik ekseninde tanımlandığında sofra pratiklerinden festivallere, beslenme kültüründen mutfak kültürüne kadar geniş bir alanı kapsayan toplumsal bir olgu olarak ortaya çıkmaktadır (Sağır, 2016a). Yemek aynı zamanda topluluklara özgü farklılaşmaların da temel kaynağıdır. Çünkü Şahin’e (2003) göre yemek kültürünün çeşitlenip özelleşmesinde "ekolojik çevre, dinsel inanç, kültürel edinimler, sosyal ve etnik gruplar, eğitim düzeyi ve kültürel miraslarının getirileri, damak zevkleri ile bütünleşmesinin etkisi büyük önem taşımaktadır.” Yemeğin sosyolojisi söz konusu olduğunda “toplumsal bütünleşmenin ve dayanışmanın da araçsallaştırılmış hali” (Sağır, 2016a) betimlemesi kapsayıcı ve yemeğe toplumsal bir çerçeve çizici durmaktadır. Sağır (2012) yapmış olduğu çalışmasında yemek-toplum ilişkisini üç alt başlıkta değerlendirip çözümlemeye tabi tutarak yemeğin bu bağlamına gönderme yapmaktadır. Bunları sırasıyla, "yemek etrafinda gerçekleşen törenleri sembolik çözümleme”, “mutfak kültürü olarak yemek 
olgusuna odaklanma" ve "yemek olgusunu beslenme kültürüyle ilişkili düşünme” olarak betimlenmiştir. Buraya bir diğer madde olarak "yemeği toplumsal değişmelerin okunduğu kültürel bir gerçeklik olarak çözümleme" ilkesini de eklemek bu çalışmaya meşru bir zemin sağlayacak olması bakımından faydalı olacaktır. Bu çalışmaya çerçeve çizen yol izleği ise Sağır'ın aynı çalışmasında yemek sosyolojisi dendiğinde geçmişten bugüne yaşanan değişimleri açıklayan 7 maddelik analiz ilkelerinden türetilmiştir. Temalar aynı zamanda yemek, beslenme ve gıda sosyolojisi literatürüyle de ilişkili bir biçimde ortaya koyulmuştur (Barthes, 1979; Fischler, 1988; Fiedlhouse, 1995; Beardsworht ve Keil, 2012; Carolan, 2012; Goody, 2013; Bourdieu, 2015; Akarçay, 2016; Belge, 2016; Beşirli, 2017; Ichijo ve Ranta, 2018).

Tablo 1

Yemek Sosyolojisi Güncel Çalı̧malar İ̧̧in Tematik Unsurlar

\begin{tabular}{|c|c|}
\hline Ana Tema & Tema içeriği \\
\hline Sentez Mutfak & $\begin{array}{l}\text { Küresel, bölgesel ve yerel mutfakların karşılaşma alanları } \\
\text { Farklı yemek kültürlerinin birbirleriyle uyumluluğu } \\
\text { Yeni bir içerik ile ortaya çıkan yemek kültürü } \\
\text { Kent ve taşra arasındaki farklılıklar ve direnç noktaları }\end{array}$ \\
\hline Beslenme Kültürü & $\begin{array}{l}\text { Küreselleşmenin değiştirdiği beslenme alışkanlıkları } \\
\text { Fastfoodlaşma } \\
\text { Yerel ve bölgesel mutfaklarda özgünlük kaybı } \\
\text { Yemek kültürü odağında yerel kimlikleri güçlendirme }\end{array}$ \\
\hline Kent Kimliği & $\begin{array}{c}\text { Turizmle özdeşlessen yemek kültürü unsurları } \\
\text { Mekânsal organizasyon ve kültürü }\end{array}$ \\
\hline Yemek Sembolizmi & $\begin{array}{c}\text { Modernleşmenin yemek ritüelleri üzerindeki yansımaları } \\
\text { Sofra adaplarının değişme biçimleri } \\
\text { Yemek araçları } \\
\text { Yemeğe yüklenen özel anlamların çözümlemesi }\end{array}$ \\
\hline Toplumsallığın Kaybı & $\begin{array}{c}\text { Tektipleşme } \\
\text { Standartlaşma } \\
\text { Paylaşım alanlarının ortadan kalkması } \\
\text { Bireyselleşme ve beslenme kültürü ilişkisi } \\
\text { Yemeğe dair zihinsel dönüşümmler }\end{array}$ \\
\hline
\end{tabular}

Tablo 1'e bakıldığında adı geçen temalar, aynı zamanda bu çalışmada katmanlaşma teorisi çerçevesinde betimlenecek yemek alanının da ilk düşünsel biçimleridir. Böylece çalışmanın ana çıkış noktası yemeğin sosyolojik bir vaka olduğu varsayımı iken daha önce literatüre kazandırılmış çalışmanın da farklı bir yaklaşımla yeniden çerçevelendirilmesi amaçlanmıştır. Ayrıca bu çalışmada yemeğin kültür ve kimliği inşa edici yönü, küreselleşmenin tek tipleştirdiği toplumsal alanda güvenlikli alanların oluşturulması veya korunması (Bauman, 2017) kaygılarına paralel değerlendirilmiştir. Böylece yemeğin sosyolojisine dair çıkarımların temel noktasının "kültürel ve toplumsal anlamlandırmalar" üzerinden gittiği (Fischler, 1988; Anderson, 1993; Murcott, 2019; Beardsworth ve Keil, 2012; Goody, 2013) ve yemek söz konusu olduğunda "sadece ne yenildiğinin değil", "nasıl, ne zaman, nerede ve niçin yenildiği”"nin (Goodman, 2011, s. 250) de önemli olduğu görülmektedir. Çalışmada yemek kültüründe iç içe geçmiş alanların toplumsal kaynaklarıyla 
ilişkilendirilmesi ve yemek kültürünün özgünlügünü korumaya çalışan alanlarını göstermesi kaygısıyla "katmanlaşma yaklaşımı" kullanılmıştır. Katmanlaşma yaklaşımı literatürün farklı yönlerinden beslenmiştir. Yemeği milliyetçilik (Ichijo ve Ranta, 2018), küreselleşme (Ritzer, 2011; Ritzer, 2019; Akarçay, 2012), kültür (Akarçay, 2016; Beşirli, 2017; ve kimlik (Carolan, 2012; Mak ve ark., 2012) ile ilişkilendiren çalışmalar literatürün temel ayağını oluştururken, göçmen mutfă̆ $l$ (Jayasanker, 2020; Cronin, 2014) ve toplumsal cinsiyet çalı̧̧maları (Fiedlhouse, 1995; Counihan ve Kaplan, 1998; Inness, 2001) da diğer bir ayağını oluşturmaktadır. Bu çalışmanın iddiasını literatürde iç içe geçişleri yeniden çerçevelendirme kaygısı oluşturmaktadır. Bu kaygıya yemeği tek bir odak üzerinden tartışan çalışmaları sosyolojiye yeni bir yaklaşımla uyarlamak eşlik etmiştir. Çalışmanın örneklemi olarak Karabük seçilmiştir. Bu tercihte birkaç farklı alt kabul etkili olmuştur. Bunlardan ilki, Safranbolu gibi eski bir yerleşim merkezini bünyesinde barındırması nedeniyle birikimsel ve tarihsel bir yemek kültürüne sahip olmasıdır. Bu nedenle Safranbolu'ya özgü yöresel mutfak kültürü oldukça geniş bir içeriğe sahiptir ve bu içerik onun araştırma olgusu haline getirilmesi için önemlidir. Bölgenin Türkmenlerin yerleştiği eski bir coğrafya olması ise Karabük'ün köylerinde ve mahallerinde Türk kültürüne ait pratiklerin varlığına kaynaklık etmiştir. Karabük'ün bir göçmen mutfağ 1 olması da ayrıca önemlidir. Çünkü Karabük, 1937 Demir Çelik İşletmeleri’nin kurulmasıyla birlikte ağır sanayi hamlesinin başladığı ve sonrasında bir Cumhuriyet Kenti olarak tanımlanan bir kimliğe sahiptir (Sağır ve Canayaz, 2017; Sağır, 2016b; Kütükçüoğlu, 2010). Sanayileşmeyle birlikte göç alan Karabük, göçmenlerle geniş bir mutfağın karışımı yemek kültürü oluşmuştur.

\section{Yemek Kültürünü Çözümlemede Yeni Bir Yaklaşım Önerisi: Katmanlaşma Teorisi}

Katmanlaşma kavramı, sınıf, tabakalaşma ya da eşitsizlikler üzerinden toplumsal alanın bir çözümlenmesi değildir. Kavramı, toplumsal alanın, bir pastanın katmanları gibi hem ayrı bölümlere hem de sistematik bir bütünselliğe sahip oluşuyla anlaşılmalıdır. Katmanlaşma, bu bağlamda toplumsal alanın katmanlarının, pasta katları gibi tatlarının birbirine geçmişliğini de içermektedir. Katmanlar, toplumsallığın gündelik hayatta kurulmasının anlaşılmasında kullanılabilecek teorik bir açıklama yaklaşımıdır. Bu katmanlar aynı zamanda yemek söz konusu olduğunda kültürlerin yerel, ulusal ve küresel bağlamda iç içe geçişlerinin ortaklıklarını ve farklılıklarını tanımlama açısından önemlidir. Katman, birbiri üzerinde bulunan yassıca maddelerin her birine verilen addır ve toplumsal alana ait parçaların belli bir sistematik dahilinde sınıflandırılmasıdır. Aynı zamanda gündelik hayatı inşa eden ve onu anlamlandıran kategorilerin ayrı ayrı izlerinin sürülmesinde oldukça önemlidir. Katmanların süreç içerisinde kendiliğinden oluşan bir özelliği vardır. Tıpkı doğadakine benzer şekilde insan müdahalesi olmadan insan ve toplum doğasına paralel şekilde oluşmaktadır. 
Burada elde edilen kazanımlar değil, toplumsal değişimler karşısında değişen zihinsel ve davranışsal tutumların pratiğe yansıması söz konusudur. Katmanlar, değişime direnci ve zamanla da uyum sağlamayı açıklama açısından oldukça kullanışlıdır. Değişim söz konusu olduğunda direnç noktalarının oluşması kaçınılmazdır. Katmanın, kültürün maddi öğeleriyle doğrudan biçimlenmiş bir yapısı vardır. Dolayısıyla katmanların biçim değiştirmeleri kolaydır. Katmanlaşma, değişimin doğal sonucu olarak karşımıza çıkar ve toplumsal alanın bölümlerini biraraya getirir. Modern kültüre ait olan tarafı budur. Değişmesi, rasyonalize edilmesi ve birtakım kurallarla çerçevesinin çizilmesi katmanların modern özellikler taşıdı̆̆ını göstermektedir. Ancak iç içe geçişlerinin benzersiz olması ve toplumsal kültürün farklı biçimlerde melezleştirmesi bağlamı post modern kültürün eklektiğiyle ilişkilidir. Burada aynı zamanda Geller'den (1994) referansla modüler mobilyalar gibi bileşenleri bir araya getirerek oluşturulan katmanlardan bahsedilmektedir. Aynı zamanda günlük değişimlerle de kalıcılık ve sabitlik özelliklerini kaybeden bir durumdan bahsedilmektedir.

Katmanlaşma teorisinin, yemek kültürünün betimlenmesinde kullanılma sebebi, yemeğin toplumsal alanda maddi alanın önemli bir temsiliyete sahip oluşudur. Yemek kültürü değişimlerden en fazla etkilenen ve en hızlı uyum sağlayan temel alandır. Mekânsal değişimler, mutfağın turistikleşmesi, yaygınlaşan fastfood, ritüellerde değişen yemek sunumları ve benzeri birçok alt başlık bahsi geçen alanı tanımlamaktadır. Nitekim yemek sosyolojisi ile ilişkili temel referans çalışmalara bakıldığında John Bennett'in 1943'te yayınlanan "Food and Social Status in a Rural Society" çalışmasında yemeğin kültürel bir değer ve sosyal süreçlerin toplamı olduğuna gönderme yapılırken yemek kültürünün toplumsal katmanlarından da bahsetmektedir (Bennett, 1943). Murcott' un 'The Sociology of Food and Eating: Essays on the Sociological Significance of Food" (akt. Yenal, 1996) çalışması da yemek sosyolojisi alanında ilk olması bağlamında insanların niçin yemek yediklerine verdiği yanıtlar, yemeğin pişirilme ve sunulması sırasında ön plana çıkan özgünlükler, yemek üzerinden maddi ve toplumsal ilişkiler tartışmalarını yaparken aynı katmanları betimlemektedir. $\mathrm{Bu}$ çalışma yemeğin sosyolojisini katmanlaşma yaklaşımı bağlamında aşağıdaki şekilde çerçevelendirmiştir. 
Şekil 1. Katmanlaşmanın Çerçevesi

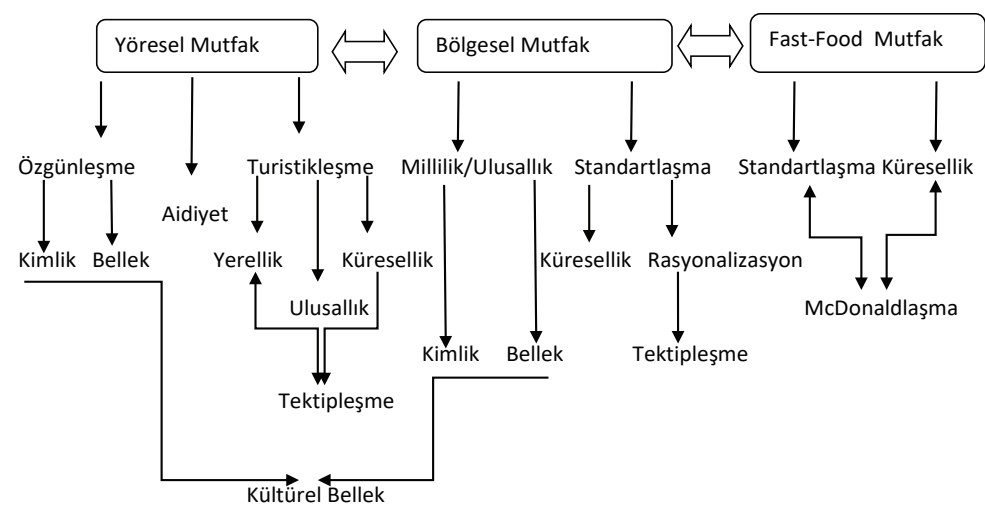

Katmanlaşmanın çerçevesini çizen ilk kategori olarak yöresel mutfak, literatürde topluluk tarafından diğer yemeklere kıyasla üstün tutulmasıyla ilişkilendirilmektedir (Şengül ve Türkay, 2015). Yöresel mutfak sıklıkla aidiyetlikle özdeş görülmektedir. Toksöz ve Aras' in (2016) yaptıkları çalışmada yöresel mutfak, yemeğe ait olan her türlü materyalin hazırlanması, pişirilmesi ve tüketilmesi, bunların yanında her türlü yiyecek ve içeceğin saklanması ve depolanması, mutfakta kullanılan araçları, yemek mekânlarının organizasyonunu, yemek törenlerini ve bu törenlerde ortaya çıkan inanç ve uygulamaları ifade eden geniş kapsamlı bir kavram olarak karşımıza çıkmaktadır. Böylece yöresel mutfağın kültürel kimlikle topluluğu birleştiren yönü ortaya çıkmaktadır. Kültürel kimlikle yöresel mutfağın özdeşliği aynı zamanda topluluk üyelerinin belleği ve hafızayı inşa etme çabası söz konusu olduğunda dikkat çekicidir. Çünkü bellek toplumsal hayatı devam ettirici bir özelliğe sahiptir (Connerton, 1999; Assman, 2001). Kültürel bellek kavramı toplumun paylaştığı değerler, etkinlikler ve fikirler üzerinden tanımlanan, tarihselleşen ve sürekliliği olan bir kolektif kimliktir (Depeli, 2010). Yöresel mutfağın alt temalarında özgünlük dışında kültür ve belleğin tanımlandığı merkezi odakta yer alan bellek, günün ihtiyaçlarına göre de sürekli yeniden inşa edilmektedir (Connerton, 1999). Böylece bellek, yöresel mutfak üzerinden gündelik hayatın sürdürülmesinde ve kuşaklararası bağlantıların sağlanmasında önemli bir araca dönüşmektedir. Halbwachs Kolektif Hafiza (2017) kitabında bireyin kolektif hafızasının ait olduğu gruptan ayrıldığı zaman dağılıp yok olabileceğini "hayatın bir dönemini unutmayı, o zaman etrafimızda olan kişilerle teması kaybetmek olarak betimlemektedir. Burada yemek kültürüyle de ilişkilendirilmiş olması nedeniyle bellekten kopuşu iki süreç temsil etmektedir. İlki göç, diğeri ise küreselleşmedir. Göç, fiziksel olarak kültürün inşa edildiği mekânın terkedilmesidir. Mekân değiştirme, aynı zamanda yerleşik kültürün de başka bir yere taşınmasını ifade eder. Göçmenlerin yerleştikleri yeni yerlerinde yaşatmaya devam ettikleri kültür belli bir kayba uğramakta ve bu kayıp sırasında göçmenin memleket aidiyetliklerini sürdürebilmek için belli direniş noktaları geliştirmektedir. Göçmen olma hali söz konusu olduğunda bellekten 
kopuşu yavaşlatma sürecinde göçmenin yemek kültürüyle ilişkisi dikkat çekicidir. Göç ettiği mekânda yöresel alanları arayış ya da geldiği memleketiyle yemek üzerinden geliştirdiği aidiyetlik bağı gündeme gelmektedir. Karabük özelinde değerlendirildiğinde Hıdırellez etkinliklerinde büyükşehirlerde yaşayan Karabüklülerin memleketlerine gelmeleri ve törenlere katılımları böyle bir bağın dışavurumuna örnektir. Hıdırellez'de yapılan birtakım ritüellerin yemek etrafında gerçekleşmesi ve etkinliklerin kurucu temasının kurban kesmek olduğu düşünüldüğünde yemeğin göçmen üzerinde aidiyet kurucu ve bellek sürdürücü bir işleve sahip olduğu tezi güçlenmektedir. Ayrıca bir örnek olması bakımından İstanbul'a yerleşen Eflanili göçmenlerin, Karabük'te yaptıkları fırıncılık/pastanecilik işini göç ettikleri ilçelerde firın ve pastane işine girerek sürdürmeleri yemekle geliştirilen bir diğer aidiyet ve bellek sürdürücü örnektir.

Küreselleşmenin ise yerel kültürler üzerine kurduğu baskıyla kopuşu hızlandırdığı görülmektedir. Her iki kopuş sürecinin doğrudan bölgesel mutfak ve fastfood mutfak kategorisine geçişi temsil ettiğini ifade etmek mümkündür. Burada yemeğe ve mekâna atfedilen anlamlar ön plana çıkmaktadır. Burada yemek kültürünün topluluğa özgü biçimleri gündeme gelmektedir. Kimlik ve belleğin bir üst bağlamı olarak düşünülmüş özgünlük, yemeğin topluluğa ait törenlerini, festivallerini, kurallarını, dışavurumlarını ve yemeğin yapılış biçimlerini tanımlamaktadır. Bahsi geçen temeller, aynı zamanda geçmişten bugüne kültürün taşınması ve kuşaklararası bağlantıyı sağlamasını ifade etmektedir. Yöresel mutfağın aidiyetlikle olan bağlantısını kimlik ve bellek bağlamından ayrıştıran temel özelliği, üyelerinin aktif bir özne olarak mutfağa dahil olduklarında kültürel belleğin bilgisinin tamamına sahip olmayışlarıdır. Burada kastedilen bağlam, kuşkusuz kültürün bir alışkanlık şeklinde sürdürülmesi ve geleneklerin kaynağını açıklayamama durumudur. Kaynağa ulaşamama, kültüre aitliği betimlemeye engel olmamakla birlikte onun çerçevesinin eksik çizilmesine neden olur. Yani yemeğin merkeze koyulduğu bir kültürel ritüelin içerisinde bulunmuş olma hali, o ritüelin kuşaklararası süreçte bugüne nasıl taşındığı bilgisine sahip olmaktan daha baskın önem taşımaktadır. Ritüelin içerisinde bulunma, birkaç farklı davranış pratiğini de bünyesinde taşımaktadır. Bunlardan ilki özellikle göçlerin şekillendirdiği bir toplumsal alanda, topluluk üyelerinin ait oldukları memlekete gidip özellikle oradaki yemek kültürüne dahil oluşlarıdır. Diğeri ise bulundukları alanı terk etmeden aidiyetliklerini yemek kültürü etrafından betimlemektir. Üçüncü bir pratik ise üç kuşak arasında bağlantının sağlanmasıdır. Yaşl1-orta ve genç kuşak, ritüelin etrafında toplandığında sözel olarak kültürü paylaşır. Kültürün paylaşımı sırasında törensel pratikler yerine getirilir. Süreç aynı zamanda bir sosyalleşme biçimi olarak ritüeli öğrenme alanına dönüştürür. Böylece ritüelin gerçekleştiği alan kimliği inşa edici bir mekândır. Burada yemeğe atfedilen anlamlar ön plana çıkmaktadır. Katmanlaşma yaklaşımının ikinci kategorisi olarak bölgesel mutfak, şehre özgü yemeklerin yanında diğer şehirlere ait mutfakların sunum biçimlerini ifade eder. Yöresel mutfak ile bölgesel mutfak, ayrı ayrı katmanlar olmakla birlikte aynı mekânsal bağlama da sahip olma potansiyelini içermeleri nedeniyle iç içe 
geçen bir özelliğe sahiptir. Dolayısıyla yöresel mutfak kategorisinde tartışılan birçok temanın bölgesel mutfak kategorisi için de geçerli olduğunu ileri sürmek mümkündür. Bu kategorinin farklı yönü ise rasyonalizasyon alt temasıdır. Rasyonelleşme, mutfağın kapitalist sistem içerisinde standartlaşmasını ve tektipleşmesini ifade etmektedir.

Katmanlaşma yaklaşımının son kategorisi ise fastfood mutfaktır. Fastfood zamanın verimli kullanılması üzerine şekillenen ve hızlı yemek yemeyi kapsayan bir yemek hizmetidir. Hizmet aynı zamanda istediğin şekilde menünün oluşturulması üzerine kurulu bir çeşit özerkliği içermektedir (French ve ark. , 2000). Merdol'a (1998) göre sinırlı sayıda ürünlerin hızlı bir şekilde hazırlanması, pişirilmesi ve sunulması sistemine verilen addır. Fastfoodun ilk biçimi 1780'li yıllarda Kuzey İngiltere'de balık-patates kızartmasının olduğu ifade edilmektedir (Tuncel, 2000). Küreselleşmeyle fastfoodun bütün dünyaya hızlı bir şekilde yayıldığı ve mutfakları dönüştürdüğü söylenebilir. Fastfood aynı zamanda McDonalds ile modern tüketim endüstrisinin bir yaşam biçimine evrilmiştir (Ritzer, 2011; Ritzer, 2019; Schlosser, 2012). Fastfoodun sembolleşmesi ve gelişmekte olan ülkelerde yöresel mutfakları kendisine benzeştirmesi de sürece eklemlenince (McBride, 2005) yemek kültürünün gelenekselden moderne geçişte klasik anlamının ötesine geçtiği görülmektedir. Böylece yerel ve bölgesel mutfağın tüketim endüstrisinin bir parçasına dönüştüğü süreç karşımıza çıkmaktadır. Kuşkusuz fastfoodun ağırlık kazanması "endüstriyel gıdaların ă̆ırlık kazanması" (Gültekin, 2019, s. 26) ile de doğrudan ilişkilidir. Benn'in (2009) "pizza ve burger”"in dünya üzerinde gezintiye çıktığı bir dönemi betimleyen süreç, Fischler'in (1998) betimlediği biçimde gıda endüstrisinin geleneksel yiyecekleri maskeleme, taklit ve kendine benzeştirmeye doğru evrilmiştir. Bu süreç katmanlaşma yaklaşımında standartlaşma alt temasına Fischler'in "modern yiyeceklerin tatlarının, kokularının ve içeriklerinin çok da tanımlanamadığı bir belirsizlik hali" vurgusuyla gönderme yapmaktadır. Kuşkusuz birçok gıdada benzer katkı maddelerinin kullanılması ve benzer hazırlama süreçlerinden geçmesi standartlaşan bir damak tadı yaratırken, bu damak tadının her bireyde benzer izlenimler yaratması yiyeceğin kimlik olarak anonimleşmesini ve anonimlik de belirsizliği ortaya çıkarmaktadır. Bu belirsizliğin varlığ küreselleşmenin aynı zamanda bir risk toplumu olduğu gerçekliğini somutlaştırır. Beck'in (2011) ifadesiyle risk toplumu yeni bir felaket toplumudur ve riskin kültüre dönüştüğü bir toplumdur. Dolayısıyla katmanlaşma yaklaşımında fastfood mutfak kategorisinin küreselliği bir alt tema olarak kullanması bahsi geçen standartlaşmanın, getirdiği belirsizlikler ve dünyanın her bölgesinde yaygınlaşmasıyla çerçevelendirilmiştir. Katmanlaşma yaklaşımında yer alan fastfood mutfağın, yöresel ve bölgesel mutfağı dönüştürücü rolünde melezlik ve yeni formlar, standartlaşmayla ilişkili olmakla birlikte farklılıkları ortadan kaldırdığı bütünsel nitelikler de taşımaktadır. Mekânlar dönüşmekte, geleneksel beslenme alışkanlıkları değişmekte ve mekân parçalanmaktadır. Mekânın parçalanışı, esnaf lokantalarının yerel, bölgesel ve fastfoodu birlikte sunması, kafelerin ise içecek kültürünün dışında yöresel, bölgesel ve fastfood mutfağı içeren menülerin entegrasyonuyla temsil edilmektedir. Bu bağlamda küreselleşme yemeği salt bir beslenme 
alışkanlığına indirgemektedir. Süreç Fischler'in (1980) gastro-anomisine uygun özelliklere sahiptir. Kavram toplulukların gelenekselden bugüne yemeğe yükledikleri kültürel anlamların, değerlerin ve kuralların çözülmeye başladığını tanımlar. Geleneksel topluluklarda mevsimsel hazırlıkları içeren konserve ve saklama kültürünün kaybı, yemeğin hazırlanışı sırasında birlikteliklerin ve paylaşımların çözülmesi, yemeğin merkeze yerleştirildiği ritüellerin standartlaşmayla birlikte toplumsal gücünün azalması küreselin yerellik karşısındaki uzantılarını temsil etmektedir.

\section{Araştırmanın Metodolojisi}

\section{Araştırmanın Deseni ve Çalışma Grubu}

$\mathrm{Bu}$ çalışma nitel prosedürler ile yürütülmüştür. Bu doğrultuda veri edinme yöntemi olarak yarı yapılandırılmış görüşme, gözlem ve literatür incelemesi yapılmıştır. Çalışmada amaçlı örneklem kriterine göre hareket edilmiş, maksimum çeşitlilik örneklemesi tercih edilmiştir. Maksimum farklılığın sağlanması kaygısıyla incelenen olguya ilişkin “deneyim” çeşitliliği tercih edilmiştir. Deneyim, yemek kültürünün farklı biçimleriyle temas eden katılımcıları ortak bir paydada birleştirme amacını içermiştir. Bu tercihe Yıldırım ve Şimşek' in (2011) vurguladığı biçimde "çeşitlilik gösteren durumlar arasında herhangi bir ortak ya da paylaşılan olguların olup olmadığını bulma kaygısı" eşlik etmiş̧ir. Böylece incelenen olgunun farklı boyutlarını ortaya koymak amaçlanmıştır. Bu bağlamda araştırmada üç farklı hedef kitle seçilmiştir ve toplam 28 kişi ile görüşülmüştür. Bu kişiler arasında Safranbolu Çarşı'da yer alan yemek ve gıda alanındaki mekân sahipleri, yemek ve gıda sektörü ile doğrudan ilişkisi bulunmayan Karabük sakinleri ve aslen Karabüklü olup İstanbul'a göç etmiş olan kişiler yer almaktadır.

\section{Güvenvericilik}

Çalışmada güvenvericiliğin sağlanabilmesi için veri edinme yöntemi üçgenlemesi yapılmıştır. Derinlemesine görüşme verileri araştırmacının katılımcı gözlemleri ve literatür ile desteklenmiştir. Araştırmacının uzun bir süredir Karabük'te ikamet ediyor olması ve araştırma sürecinde konumuna yapılan vurgu bu bağlamda önemsemiştir. Böylece araştırmacının kullandığı veri toplama araçları, incelediği fenomenin kültürel anlamını çözmeyi hedeflerken elde ettiği veriler üzerinde de araştırmacının kendi algısını da gösterme kaygısı taşımıştır. Konuyla ilgili farklı toplumsal gruplarla görüşme yapılması ile de örneklem çeşitliliği yakalanmaya çalışılmış ve aynı zamanda veri kaynağı üçgenlemesi de sağlanmıştır. Farklı gruplarda ön plana çıkan ortak deneyim alanı yemek kültürünün anlamlandırılması iken, İstanbul'da Karabüklü olmak, kültürel belleğin sürdürülmesini sağlamak ve Karabük’te tüketici olmak farklılıkları oluşturan deneyimler olmuştur. ${ }^{1}$.

1 Çalışmanın uygulama sahası için etik kurula başvurulmuş ve "2020/03" sayılı toplantı ile çalışmanın etik kurallara uygunluğu oybirliği ile kabul edilmiştir 


\section{Verilerin Toplanma Süreci}

Çalışmada veri toplama süreci üç alanda gerçekleşmiştir. Yöresel mutfağın alt kategorilerini oluşturan özgünlük ve turistik başlıklarının içeriklerini oluşturmak adına Safranbolu Çarşı' da yemek ve gida temalarına sahip mekânların (kafe, lokum, restoran) işletmecileriyle mülâkatlar gerçekleştirilmiştir. Mülâkatlarda 12 katılımcıya, Safranbolu'nun yemek kültürünü betimlemeye yönelik "Safranbolu yemek kültürünün içerisini nasıl doldurdukları", "yerli ve yabancı turistlerin tercihleri ve yemeklere yükledikleri anlamların betimlenmesi", "mekânın yemek kültürü içerisindeki ayrlcalıkl yeri" ve "kültürü̈n korumasında üstlendikleri misyonu tanımlayıcı bileşenlerin çerçevelenmesi” konuları hakkındaki soruları yanıtlanması hedeflenmiştir.

Çalışmanın diğer veri toplama alanı ise kent kimliği ile özdeşleşsen yemek kültürünün bir başka kent içerisinde mekân inşa edici ve mutfağı dönüştürücü yönüne odaklanarak seçilmiştir. Burada Karabük’te ikamet eden yerel sakinlerin farklı kent mutfaklarına ait mekânlarla kurdukları bağların değerlendirilmesi üzerinden mülâkatlar gerçekleştirilmiştir. Mülâkat 8 farklı katılımcı ile tercih ettikleri mekânlarda gerçekleştirilmiştir. Mekân katılımcıların tercih edilmesinde iki alt izlek tercih edilmiştir. Bunların ilki Karabük ile Safranbolu ortaklı̆ğını yansıtan ve mutfağında tarihsel ve yöresel belleği sürdüren mekânların müdavimleridir. Diğer bir tercih sebebi ise yöresel mutfak ile bölgesel mutfağı birleştiren mekânların müdavimleridir. Mülâkatlarda katılımcılara "kentlere özgü yemek kültürlerinin anlamlandırllması", "yemek kültürünün bölgeden bölgeye değişimlerinin ve yaygınlı̆̆ının nedenlerinin tespit edilmesi", "iki farklı mutfağın birlikteliğinin yöresel yemek kültürü̈n̈̈ asimile edip etmeyeceği " ve "yeni bir özgün form olarak değerlendirilip değerlendirilemeyeceği” konuları hakkında sorular sorulmuştur. Aynı bağlamın farklı bir yol izleği olması bakımından İstanbul'a göç etmiş ve Hıdırellez zamanında Karabük'e gelen 8 katılımcı ile yemek kültürü ve şehir kimliğinin özgünlük ve aidiyet bağlamında hikayesinin izi sürülmüştür. Katılımcıların "aidiyetliklerini tanımlama biçimleri", "göçmen olarak yaşadıkları büyükşehirde değiş̧imlerden korunma biçimi olarak yerelle geliştirdikleri ilişskiselliğin yorumlanması" ve "kuşaklararası bağları sürdürmede etkinliğe katılmaya" nasll bir anlam yükledikleri" konusundaki tutumları sorgulanmıştır. Çalışmanın son bölümünde ise fastfood kültürünün Karabük'te yarattı̆̆ değişimlere odaklanılmıştır. Bu kısım araştırmacının gözlemlerinden elde ettiği verilerle inşa edilmiştir ve araştırmacının doğrudan konumunu yansıtmaktadır.

\section{Verilerin Analizi}

$\mathrm{Bu}$ çalışmanın verileri analiz edilirken odaklanılan temel sorular şunlar olmuştur. Yemeğin kültürel bellekle kurduğu ilişki nasıl ve hangi araçlarla gerçekleşmektedir? Yemekle aidiyetlik geliştirilirken kişiye hangi anlamlandırmalar eşlik etmektedir? Mekânın yemeği dönüştürmesinde hangi görünümler ortaya çıkmaktadır? Araştırmada kullanılan tema ve kategoriler ise şu şekilde oluşturulmuştur: 
Tablo 2

Analizin Temalarl

\begin{tabular}{|l|c|c|c|}
\hline Temalar & Esnaf & Tüketici & Göçmen \\
\hline Mekânsal Konumlandırma & $\mathrm{x}$ & - & $\mathrm{x}$ \\
\hline Turistik Anlamlandırma & $\mathrm{x}$ & - & - \\
\hline Anlamlı Farklılık & $\mathrm{x}$ & $\mathrm{x}$ & $\mathrm{x}$ \\
\hline Sentez Görünüm & - & $\mathrm{x}$ & $\mathrm{x}$ \\
\hline Kimliklendirme & $\mathrm{x}$ & $\mathrm{x}$ & $\mathrm{x}$ \\
\hline Aidiyetlik Kurma & $\mathrm{x}$ & $\mathrm{x}$ & $\mathrm{x}$ \\
\hline Özgün Form & $\mathrm{x}$ & $\mathrm{x}$ & $\mathrm{x}$ \\
\hline Yerelle Kurulan İlişki & - & $\mathrm{x}$ & $\mathrm{x}$ \\
\hline Ulusal Dışavurum & $\mathrm{x}$ & $\mathrm{x}$ & $\mathrm{x}$ \\
\hline
\end{tabular}

Yıldırım ve Şimşek' in(2011) nitel araştırmada "bütüncül bir resim elde etmeye" yönelik yaptığı vurgu, çalışmada tümevarımsal bir veri analiz stratejisi izlenmesine kaynaklık etmiştir.

\section{Yemeğin Kültürel Bellekte İzdüşümleri (Karabük Örneği)}

\section{Safranbolu Çarşı’da Yemeğin İzini Sürme}

Safranbolu'da yemek kültürüne bakıldığında Türkmen mutfağı ile Anadolu'nun yerli mutfağ 1 dikkat çekmektedir (Canbulat, 2017). Safranbolu'da yapılan yöresel yemeklere bakıldığında gözleme, kuyu kebabı, göbü, kara mancar, katlaç, bükme, yayım, peruhi, su böreği, etli yaprak dolması, safranlı zerde, ev baklavası ve lokum (Altundağ, 2018) dikkat çekmektedir. Safranbolu yemek kültürünün içerisinin nasıl doldurulduğunda dair katılımcılara yöneltilen soruda "yöresel mutfak" kategorisinin üç alt başlığıyla ilişkili 5 farklı yanıt karşımıza çıkmıştır. Bu değerlendirmelere göre Safranbolu'da yemek kültürünün "Saray Mutfağı" (K1, K5, K7, K11) ile olan ilişkisini kuran katılımcılarda kimlik ve belleğe yapılan vurgu ön plana çıkmıştır. Burada doğrudan alanın tarihle olan ilişkisi kurulmakta ve geçmişten bugüne yaşatılan kültürel bir gelenek olarak mutfağa gönderme yapılmaktadır. Mutfağın "turistik" (K3, K6, K12) olmasına yapılan vurgu, yörenin yurtiçinden ve yurtdışından çok sayıda turist almasıyla ilişkilidir. Kuşkusuz Safranbolu'nun UNESCO tarafından dünya miras listesine alınması ve oldukça eski bir kültüre sahip olması turistik açıdan ziyaretçi sayısını da oldukça yükseltmektedir. Dolayısıyla Safranbolu mutfağının "turistikleşme" kategorisi altında küresel ve yerel başl lğına uygun bir yemek kültürüne sahip olduğunu söylemek mümkündür. Ayrıca "talebe göre menüyü hazırlama" (K10) yanıtını veren katılımc1 da bu bağlamda Safranbolu' da yemek kültürünün gelen turistlerin beğenilerine göre şekillenen bir mutfak olduğu yargısını güçlendirmektedir. Yöresel mutfağın "aidiyet" alt başlığına uygun olarak "Safranbolu ile özdeşlik" (K4, K9) kuran katılımcıların varlığı dikkat çekmiştir. Safranbolu ile özdeşlik, aynı zamanda "hiçbir yerde olmayan yemekleri" (K5, K11) ifade etmektedir. Özgünlük, kültürün kendine has kısımların küresel ve bölgesel etkiler karşısında varlığını sürdürmesini 
betimlemektedir. Özgünlüğü bir kimlik öğesine dönüştüren diğer durumlar ise katılımcılar tarafından "kendine özgü bir Safranboluluk imajı" (K2) ile ilişkilendirilmiştir. Bu bağlamda özgünlüğü ve imajı güçlendiren temel göstergeler, kullanılan malzemelerin hazırlanışı, pişirme biçimleri, yemeğin sunumu ve yemeğin adlandırılması olarak karşımıza çıkmaktadır. Yerellik ile küreselliğin birleştiği noktayı ifade etmesi bakımından katılımcılardan birisi "her yerde karşılaşabilecek yemekler" (K8) yanıtını vermiştir. Yöresel mutfağın dışına taşarak turizmin tek tipleştirdiği bir yemek kültürü (Stanley ve Stanley, 2015) gidilen her destinasyon bölgesinde "sarma, mantı, döner, lokum, pide vb. " ile karşılaşılmasına neden olmaktadır. Böylece yöresel farklılıkların ortadan kalktığı ve mutfağın birbirine benzediği bir sürece evrilmektedir. Bir katılımcı bu durumu Safranbolu'da yemek kültürü aslında anonim bir yemek kültürü var: "Yani erişte her yerde var. Peruhi değişik isimlerde her yörede var. Mantı zaten öyle” (K8) şeklinde ifade etmektedir.

Safranbolu yemek kültürünün izdüşümünü süren bu çalışmada katılımcılara yöneltilen sorulardan bir diğeri "yerli ve yabancı turistlerin tercihleri ve yemeklere yükledikleri anlamların betimlenmesi"ne dönüktür. Katılımcıların sıklıkla vurgu yaptıkları nokta Safranbolu mutfağının "turizme dönük" (K10, K3, K6, K12, K2) düzenlenmiş olmasıdır. UNESCO dünya miras listesine girmesinden sonra Safranbolu'nun turizme dönük inşa edilmesi literatürde sıklıkla dikkat çeken bir noktadır. Özellikle Karabük'te Demir Çelik İşletmeleri'nin kurulmasından sonra Karabük'ün gölgesinde kalan Safranbolu'nun 1992 yılında koruma altına alınmasıyla ekonomisinin turizme dönük planlandığ 1 görülmektedir. Ticari işletmelerde yöresel yemeklerin bir pazar nesnesi haline gelmesi Safranbolu'nun turizm kentine dönüşmesinin de bir yansımasıdır (Altınöz, 2019, s. 1221). Yöresel mutfak aynı zamanda kültürel gelenekleriyle de örüntülediği mutfağıyla turizme özgün bir değer katmaktadır (akt. Şengül ve Türkay, 2016, s. 64). Uğur ve arkadaşlarının (2018, s. 36) yerli turistler üzerinde yaptıkları çalışmada da Safranbolu imajının güçlü olmasında kentle özdeşleşmiş lokum ve safranın ön plana çıktığına vurgu yapılmıştır. Böylece turizme dönük inşa edilen mutfak, bir süre sonra turizmin inşa ettiği bir mutfağa dönüşmektedir. Kuşkusuz turizmin yöresel mutfağı standartlaştırdığına dair de eleştirel bir tutumun takınıldığı görülmektedir. Buradaki vurgu "yöresel yemek üzerine kurulu dükkanların sayısının artışılla yemeklerin kalitesizleşmesi ve sıradanlaşması" (K8, $\mathrm{K} 5$, K11) üzerinedir. Bu konuyla ilgili olarak İbrahim Canbolat "Çarşı 'da Yeme-İçme Üzerine” (2019) başlıklı çalışmasında Safranbolu lokum örneğiyle bahsi geçen durumu betimlemiştir. Safranlı lokum, Safranbolu'nun kendine özgü yemek kültürünün bir unsuru iken, sonraları aşırı rekabet altında nasıl evrildiğine dikkat çeken Canbolat, "şu an üretici ve satıcıların sayılarını tam olarak bilmesem de Safranbolu'nun en az 200 yıllık bir ekmek firınının yıkılarak bir lokumcuya dönüşü̈rülüyor olması konunun vehametini çok iyi örneklemektedir" betimlemesiyle katılımcıların "kalitesizleşme" ve "sıradanlaşma" dediği bağlama gönderme yapmaktadır. Nitekim Uğur ve 
arkadaşlarının (2018, s. 36) yaptıkları çalışmada da "yöresel yemekler" ile ilgili yerli turistlerin algılarının zayıf olduğunun ortaya çıkması Canbolat'ın yargısını dolaylı yoldan desteklemektedir.

Mekân, yemek kültürünün sürdürülmesinde önemli bir faktördür. Mekân, hem yemek kültürüne fiziksel bir çerçeve çizmekte ve onun gündelik hayata sabitlenmesini sağlamakta, hem de kültürün soyut boyutunun somut hale getirilmesini yansitmaktadır. Böylece kültürün kuşaklararası bağı mekân aracılığıyla sürdürülmektedir. Yemek kültürünün toplumsal alanda oluşturduğu katmanların betimlenmesi ve kategorileştirilmesinde kuşkusuz mekân unsurunun önemli bir etkisi vardır. Tarih-yemek, bellek-tarih ilişkisi başta olmak üzere yemek üzerinden oluşan farklı soyut ilişkilerin çerçevelendirilmesinde mekânın ayrıcalıklı yeri, aynı zamanda ona gündelik hayatı düzenleyici işlev yüklemektedir. Bu bağlamdan hareketle katılımcılara yöneltilen bir diğer soru ise "mekânın yemek kültürü içerisindeki ayrıcallkl yeri" nin tespit edilmesine dönüktür. Verilere bakıldığında mekânda "yöre"(K5, K11) adlandırılmasına oldukça önem verildiği görülmektedir. Yöre, aynı zamanda kendine özgün bir yapıyı ve kültürü yansıtmaktadır. Yöreye ait olan ürünler ise "yörenin tarihi ve kültürel bir parçasıdır" (Karaca, 2016). Yöre, küreselleşme karşısında yerelliği temsil etmekte ve turistik bir mutfağın kendine özgü sunum biçimlerine gönderme yapmaktadır. Yörenin kendine ait özgün yanı aynı zamanda onun topluluklar için yaşam sürecinin ayrılmaz bir parçası olarak kalıcılı̆̆ ifade etmektedir (Demirer, 2010). Bu bağlamdan hareketle katılımcıların mekânda "Safranbolu'ya özgü yemeklerin yapılmasına" (K2) verdikleri önem, mekânla ilişkili bir diğer bağlamdır. Ayrıca binanın tarihi bir geçmişinin olmasına verilen önem ile diğer yemek mekânlarından kendini ayrıştırma hikayesinin de burada katılımcıların aktarımlarına eşlik ettiği görülmektedir. Burada söz konusu olan temel nokta "mekânın otantik kurulumu ve organizasyonunun" (K3, K6, K12) mekân-yemek kültürü ilişkiselliğinde önemli olduğu gerçekliğidir. Böylece yöre ile yemek kültürünün fiziksel olarak bir mekânda tarih, bellek ve toplumsal ilişkileri uyumlu bir şekilde biraraya getirmesi beklenmektedir. Katılımcıların söylemlerinde ön plana çıkan tarih, "Safranbolu'nun saray mutfăğ olmasından zengin içerikli bir mutfak oluşuna" (K1, K5, K7, K11) gönderme yapmaktadır. Toplumsal ilişkiler, yemek kültürü etrafında şekillenen mekânsal inşa biçimleridir. Bu bağlam turist-esnaf ve turist-yöre insanının karşılıklı etkileşimlerini kapsamakta ve bu ilişkilerin mekânsal kurulumuna gönderme yapmaktadır.

Katılımcıların yemeği kültürel bir unsur olarak tanımlaması, onun aynı zamanda toplumsal alanı kuşatıcı bir içeriğe sahip olduğunu gösterir. Yemeğin bir kültür olarak içeriğini dolduran şeyler yemeğin pişirilme biçimlerinden mekâna, kullanılan malzemelerin yöresel olarak farklılaşmasından damak tadı kavramına eşyaları, materyalleri, mekânı, ritüelleri ve birçok göstergeyi kapsamaktadır. Bu bağlamda katılımc1lara yöneltilen "kültürün korunmasında nasll bir misyon üstlendikleri" sorusuna verilen yanıtlara bakıldığında "Safranbolu'da kültürel mirası tamamlayan 
önemli bir parça"' $(\mathrm{K} 5, \mathrm{~K} 1, \mathrm{~K} 7, \mathrm{~K} 8)$ olduklarına yapılan vurgu çoğunluğun kendilerine yükledikleri misyon olarak dikkat çekmiştir. Katılımcılar bahsi geçen misyonun çerçevesini "Safranbolu'da tarihi ve kültürel hikâyeyi devam ettirme”"(K2, K4, K12), "geleneksel ritüellerin sürdürülmesini sağlama" (K11), "kuşaklararası bağlantıyı sağlama"(K9, K6) ve "gündelik hayatı inşa edici" (K3, K5, K10) yönlerine vurgu yaparak altını çizmişlerdir. Safranbolu'nun tarihi ve kültürel hikayesi, burasının oldukça eski bir yerleşim yeri olmasıyla ilişkilidir. Safranbolu'nun tarihi geçmişi, sentez bir mutfağa sahip olmasının da birincil kaynaklarından birisi olmuştur. Dolayısıyla katılımcıların Safranbolu'nun hikayesine yaptıkları vurgu, hikâyenin bir parçası olma kaygılarıyla doğrudan ilişkilidir. Hikâyeyi ise "yöresel olana sahip çıkmakla"(K4), "kültürü mekânsal alanda somutlaştırmayla"(K2) ve "piyasa kültürüne karşı direnmekle"(K12) inşa ettiklerine inanmaktadırlar. Geleneksel ritüellerin sürdürülmesine yapılan gönderme katılımcıların aktarımlardan hareketle "baba mesleğini devralma" ve "yemek kültürü etrafinda bir araya gelerek toplumsal olma halini sürdürme" biçiminde anlamlandırılmıştır. Baba mesleği ifadesi, Safranbolu' da şeker ve lokum gibi geleneksel lezzetlerin geçmişten bugüne bir "aile belleği” biçiminde aktarımıla ilişkilidir. Toplumsal alanın sürdürülmesi ise "mantı, peruhi, pide ve sarma gibi birçok yemeğin hazırlanışı sırasında biraraya gelişleri", "kahve kültürü etrafinda farklı sosyalleşmeleri (içme, müzik dinleme, sohbet, eğlenme)", "yemek mekânlarında turistlerle gerçekleşen etkileşimleri", "belli törensel işlevlerle yemek yemeyi (sofranın adabına uyulması ve mekânsal organizasyona uyum sağlama)" ve "geçiş ritlerinde (doğum, düğün ve ölüm) hem insanların rahatlatılmasinda hem de yemeğin bir eğlence veya yas materyaline dönüşmesini" kapsamaktadır.

\section{Bir Göçmen Mutfağı Olarak Karabük’te Katmanlaşan Gündelik Hayat}

\section{Yeni Bir Form Olarak Dönüşen Yemek Kültürü}

Karabük, Demir Çelik Fabrikaları'nın kuruluşuyla birlikte Türkiye'de örnek bir sanayi kenti olarak doğmuştur. Türkiye Cumhuriyeti'nin kuruluş döneminde ağır sanayinin merkezi yeri olan Karabük, sadece bir sanayi kenti olarak değil sosyal ve kültürel anlamda da özgün bir kentsel kimlik hikayesine sahip olmuştur. Müstakil ve bahçeli evleriyle Yenişehir'in örnek bir mahalle olarak kuruluşu, Sümerkent ismiyle geleceğin Türkiye'sine örnek bir mahalle olarak kurulan Beşbinevler'in varlığı ve fabrikalar etrafinda gelişen fiziksel, sosyal ve kültürel doku bu hikâyenin tamamlayıcı parçaları olmuştur. Ancak Karabük’te sürecin tersine döndüğünü de belirtmek gerekir. Suha Arın'ın yönetmenliğinde “Safranbolu'da Zaman" belgeseli (1977) ve koruma alanındaki akademik çalışmalarla turizm alanına başlangıç yapan Safranbolu'nun, 17 Aralık 1994 yılında UNESCO Dünya Miras Listesi’ne alındıktan sonra popüler bir turistik merkeze dönüşmesiyle birlikte Karabük'ü gölgesinde bıraktığı ve ön plana çıktığ1 görülmektedir. 
Katılımcılara yöneltilen ilk soru "özgünlüğ̈̈̈n bir parçası olarak yemeğin nasıl anlamlandırllabileceği”" ne yönelik olmuştur. Bu noktada dikkat çeken temel bağlam öncelikle katılımcıların birbirinden bağımsız bir şekilde soruya "yemek yemenin bir ihtiyaçtan öte kimliksel dı̧̧avurum olduğu" na dair yapılan çıkarımla ilişkilendirilmiştir. Yemek yemenin bir ihtiyaçtan öte her toplumun kendine özgü bir yemek ve mutfak kültürü bulunmasına yapılan atıftır. Şahin'e (2010, s. 3) göre çevre, dinsel inanç, kültür, sosyal ve etnik gruplar, eğitim düzeyi ve kültürel mirasın getirileri, yemek kültürünün çeşitlenip özelleşmesinde büyük rol oynamaktadır. Şahin'in vurgusu yemeğin aynı zamanda bir kimlik göstergesi olduğu gerçekliğine dönüktür. Katılımcıların aktarımlarına bakıldığında Karabük'te yemek için tercihte bulundukları mekânlarda yemeğin görünümlerine "adlandırma" (T2, T7, T8), "yemeğin sembolik değeri” (T1, T5), "topluluğun dışa karşı kendini farklılaştırması” (T3) ve "aitlik hissetme" (T4) ve "damak tadl”(T6) olarak değer atfettikleri görülmüştür. Adlandırma, daha önce Safranbolu özelinde tarihi çarşının kültürel özgünlüğünün ve tarihsel belleğinin sürdürülebilirliğinde etkin bir eylemdir. Yemeğe verilen ismin "şehrin kendisini yansıtır bir özelliğine sahip olması gerekliliğini" savunan katılımcılar(T2, T7, T8), kentte yetiştirilen tarımsal ürünlerin bir yansıması, mekânın kullanılma biçimlerine özgü formlar, yemekle ilişkili ritüeller ve materyaller, yemeğin hazırlanma ve sunulma biçimleri gibi üç farklı alt kategori eklemlemişlerdir. Mekânın kullanılma biçimlerine atıf temelde mutfağın organizasyonuna gönderme yapmakla birlikte yemeğin yendiği mekânların organizasyonunu da kapsamaktadır. Tarımsal ürünlerle şehrin özdeşliğinin yemek kültürünün kendine özgün formunu ortaya çıkarması bağlamında adlandırmanın önemli bileşenlerinden bir diğeri olarak görülmüştür. Deniz ürünlerinin ya da tahıl ürünlerinin kullanılması, yemeklerde tercih edilen et, sebze ve yağ türleri gibi birçok detay bu alt kategorinin betimlemesi olarak ortaya çıkmıştır. T1 ve T5'nin ifade ettiği sembolik değer, toplumsal ve dinsel törenlerde yemeğin kullanılma biçimlerine atıf yapmak için kullanıldığı göze çarpmaktadır. Törenlerin dışavurumu ya da törenlerin etrafında yapıldığı bir unsur olarak yemek, karın doyurmaktan ziyade kültürel bir eyleme ve kent kimliğinin sunum biçimlerine dönüşmektedir. Törensel kutlamalar ve yemeğin sunum biçimleri bölgeden bölgeye de değişmektedir. Topluluğun kendini dışa karşı farklılaştırması T3 tarafindan hem "özgünlük" olarak yorumlanmış hem de "insanların birbirleriyle etkileşim kurdukları alanların başında nerelisin sorusundan sonra yemek muhabbeti" olarak okunmuştur. Göçmenliğin yaygın bir toplumsal gerçeklik olduğu Türkiye'de özellikle büyükşshirlerde yaşayanların mutfakla geliştirdikleri ilişkiyi de "özgünlügün bir dışa vurumu” (T3), "ben kimim sorusuna verdikleri yanıt" (T1) ve "özlem ve hasret giderme" (T6) olarak değerlendirmişlerdir. Burada özlem ve hasret gidermenin aynı zamanda şehirde güvenlikli bir koza tarafından çevresini çizmeye çalışan göçmenin bir kavrayış tarzı olarak düşünülmesi de ayrıca dikkat çekici bulunmuştur. Böylece mutfak, farklı şehirlerde göçmen olarak yaşayan bireyin, ait oldukları "ata 
toprağıyla somut olarak kurdukları" (T5, T2) sürekli üretilen bir ilişkinin yansımasına dönüşmektedir. Katılımc1lara yöneltilen diğer bir soru "yemek kültürünün bölgeden bölgeye değişimlerinin ve yaygınlığının nedenlerinin tespit edilmesi"ne dönük olmuştur. Bu bağlamda katılımcılara yöneltilen sorudan hareketle "yemek kültürünün bölgesel farklılıklarının" nedenleri şu şekilde kategorize edilmiştir.

Tablo 3

Yemek Kültüründe Bölgelerarası Farklılıkların Anlamlandırılması

\begin{tabular}{|l|c|}
\hline Katılımcılar & Farklılıkların Kaynağı \\
\hline T1 & Coğrafya, tarım ürünleri, iklim \\
\hline T2 & Coğrafya, yetiştirilen ürünler, kültür \\
\hline T3 & Kültür, coğrafya, din \\
\hline T4 & Gelenek, görenek, coğrafya, din \\
\hline T5 & Coğrafya, kültür, din \\
\hline T6 & Kültür, yetiştirilen ürünler, din \\
\hline T7 & Tarım, coğrafya \\
\hline T8 & Din, kültür, tarım, coğrafya, mutfak \\
\hline
\end{tabular}

Tablo 3'e bakıldığında coğrafya katılımcıların büyük bir çoğunluğu tarafından farklı1ıkların ortak kaynağı olarak görülmüsstür. Yemek kültürü farklılıklarında coğrafyanın oynadığı rolün detaylandırılmasında tablodaki görülen diğer yanıtlara paralel verilerin ortaya çıktığı görülmüştür. Bölgelere göre değişen tarımsal üretim, denize yakınlık ya da iç bölgelerde yaşayış, taşrada ya da kentte yaşıyor olmak, iklim koşulları ve birçok fiziksel unsurun coğrafyanın alt başlığı olarak sunulduğu görülmektedir. Yemek kültüründe farklılıkların diğer kaynaklarının toplumsal kökenleri ise kültür, din ve gelenek olarak sunulmuştur. Kuşkusuz yemek sosyolojisi literatüründe kültürün, yemek kültürünün nasıl bir kimlik tanımlama aracına dönüştüğüne yapılan vurguyla araştırmanın verileri örtüşmüştür. Karabük özelinde yemek üzerinden yapılan tartışmanın bu bölümü aynı zamanda farklı mutfakların birlikteliğinde ortaya çıkabilecek süreçlerin betimlenmesini içermektedir. Bu bağlamda katılımcılara yöneltilen "iki farklı mutfağın birlikteliğinin yöresel yemek kültürünü asimile edip etmeyeceği” "sorusuna verilen yanıtlarda çoğunluğun süreci "zenginlik"(T1, T2, T4), "sentez ve yeni bir mutfak"(T5) ve "dönüştürme"(T8) olarak okudukları görülmüştür. Burada özellikle dönüştürme ifadesinin karşıllk geldiği anlam derinlemesine sorgulandığında yöresel mutfağın tamamen ortadan kalkmadan diğer yemek kültürleriyle benzeşmeye başladığına yapılan vurgu olmuştur. Benzeşme, yemek kültürünün standartlaşması veya piyasalaşmasından ziyade olumlu olarak düşünülmüş yeni bir kültürel sürecin ortaya çıkışına gönderme yapmaktadır. Kuşkusuz bu bağlam, sentez iddiasıyla da örtüşmektedir. Sentezlik vurgusu yöresel yemekler üzerinden kültürel belleğin sürdürülme çabasını da yansıtmaktadır. Ancak aynı süreci olumsuz olarak değerlendiren katılımcılardan birisi iki farklı mutfağın birlikteliğini yöresel yemek kültürünün "kayboluşu” ve "ötekileştirilmesi”"(T3) olarak değerlendirmiştir. Yöresel yemeklerin yapımının "masrafll" ve "zaman alıcl" olduğuna vurgu yapan 
katılımc1, diğer mutfakların Karabük mutfağına göre hem malzeme açısından hem de pişirme-sunum açısından kolay olduğunu ifade etmiştir. Ayrıca "kebap yapmak kolay ama peruhi yapmak zor mesela"(T3) ya da "Safranbolu pidesi yapacağına etli ekmek yapmay daha zaman almayan bir yemek olarak buluyor"(T3) söyleminin de yemek kültürünün kaybıyla ilgili güçlü bir betimleme olduğu görülmüştür. Ancak katılımc1, burada ötekileştirme kavramıyla iki farklı süreci ortaya koymaktadır. Bunlardan ilki bir önceki ifadesiyle yöresel yemeklerin yapılmasını tercih etmeyen mekân sahiplerinin tercihleriyle ortaya çıkan süreçtir. Diğeri ise yemek tercihlerinde pahalı olmasından dolayı yaygın mutfakları tercih eden müşterilerin varlığıyla açıklanmıştır. Böylece ötekileştirme kavramı kendiliğinden gelişen bir durum olarak değil, mekân sahipleri ve müşterilerin tercihleriyle ortaya çıkmaktadır. Zamanın planlanması, pahalılık ve masrafların azaltılmasının birincil derecede yöresel yemek kültürü üzerinde önemli baskı unsurları olduğu görülmektedir. Kuşkusuz bahsi geçen bu baskı unsurları küreselleşmenin dönüştürdüğü yerel kültürün dışa yansıma biçimleridir. Katılımcılardan küresel dönüşümlerle ilişkilendirilebilecek bu birlikteliği "fastfoodun zaferi”"(T6) ve "paranın zaferi"'(T7) şeklinde yorumlamıştır. Fastfoodun daha kolay ve ucuz olduğunu belirten katılımc1 "zaman kazanmak isteyen birçok insanın yemeğe ayrıca zaman ayırmak istemediğini" (T6) söylerken bunun da bir süre sonra "fastfoodlaşan yöresel mutfak ortaya çıkardığını"(T6) belirtmiştir. Söylemin derinliğine inildiğinde aynı katılımcı "içinde etin dahi olmadı̆̆ hazır mantıyı marketten alıp yöresel mantı diye insanlara sunuyorlar" ş̧eklinde detaylı bir örnek sunmuştur. Kuşkusuz katılımcı burada market mantısının sunumunu etik bir problem olarak değerlendirmekten ziyade mekânın "müşteriye hızlıca sunum yapmasının kolay bir yöntemi"(T6) olarak değerlendirmiştir. Burada fastfooda yüklenen bireysel anlamın "zamanın hızlandırılması" olduğu görülmektedir.

Katılımc1lara yöneltilen son sorunun bir önceki soruyla paralel olarak düşünüldüğünü ifade etmek mümkündür. Mutfakların kesişme noktasının “yeni bir özgün form olarak değerlendirilip değerlendirilemeyeceği" konusunda katılımcıların verdikleri yanıtlara bakıldığında karşımıza çıkan noktaları üç farklı perspektifte değerlendirmek mümkünüdür. Bunlardan ilki Karabük mutfağını geçmişle ilişkilendiren ve bugüne kadar pek çok kültürü içerisinde barındırdığına dair yargıyla ilişkilidir. Katılımcılardan bazıları bu bağlamı "Karabük'ün sanayi kenti olması nedeniyle birç̧ok yerden gö̧ç aldiğl ve göçmenlerin kendi kültürleriyle mutfağl yeniden inşa ettikleri” "görüşünü(T1, T4, T5, T8) ifade etmişlerdir. Burada göçün Karabük'ün 1937 y1lından sonra kimliğini belirleyici bir alt kategori olarak ele alındığ görülmektedir. Diğer bir perspektif ise et ve kebap kültürünün hızlıca yaygınlaşmasının her yerde aynı standartlaşmaya yol açtığ 1 ve sürecin belli bir özgünlükten ziyade “benzeşme ve tektipleşme" (T6, T7, T2) olarak yorumlanması gerektiğine dikkat çekmektedir. Perspektiflerin sonuncusu ise süreci bir kayıp olarak görmekte ve hem "Safranbolu'nun tarihi belleğinin standartlaşma baskısı altında yok olduğuna"(T3) 
vurgu yapmakta hem de “Karabük'ün yerel mutfağının özgünlüğünün ortadan kaybolduğuna”(T3) gönderme yapmaktadır.

\section{Göç-Aidiyet İlişskisinde Mutfak, Yemek ve Kültür}

Hıdırellez, Anadolu'da çok farklı biçimlerde yaygın olarak kutlanan geçiş törenlerinden birisidir. Geçiş ritlerinin temel özelliklerinden birisi fiziksel olarak yaşanan değişimlerdir. Burada yeni bir durumsallığa geçiş süreci dikkat çeker. Bu geçişlerde geçmişten bugüne uygulanan birçok ritüel vardır. Bu ritüellerde ortak noktalardan birisi yemek iken diğeri ise kurban ve adaktır. Bahar festivalleri de böyle bir geçiş törenidir ve fizik ötesi alanın da dahil edildiği bir ritüeller toplamından oluşur. Bu çalışmayla ilişkilendirilmesi bakımından özellikle büyükşehirlerde yaşayan Karabüklü göçmenlerin kimliklerinin ve memleket aidiyetliklerinin sürdürülmesinde yeni bir araçsallığı gündeme getirmektedir. Yerel topluluklar üzerinden gidildiğinde Türkiye'de toplumsal değişmeye dirençli birçok kentdışı alanlar bulunduğu görülmektedir. Değişime dirençli kültürel unsurlardan örülü kapalı topluluk olma, bu alanların ortak niteliği olarak göze çarpmaktadır. Yüksek güvenlikli bir kültürel topluluğun yaşam alanı olarak tanımlanabilecek bu yerler, aynı zamanda insanların modern hayattan kaçarak sığındıkları korunaklı barınak olma özelliği de taşımaktadır. Özellikle göçlerle büyükşehirlere gitmiş insanların zihninde bu yerler, kendilerini güvende hissetmek için korunaklı duvarlarla inşa edilmiş bir memleket algısı olarak belirmektedir. Bireyler, ihtiyaç hissettiklerinde güvenlikli kapalı topluluklarına girmekte, normal zamanlarda da memleketleriyle temaslarını sürdürmekte ve kendilerini bu ilişkisellikte tanımlamaktadırlar. Burası onları için koruyucu bir kozadır. Kozanın etrafını güvenlikli hale getiren korunaklı duvarlar kültürel pratikler oluşturmaktadır. Kültürün bireye kimlik ve aidiyet sağlama işlevi, böylece bireyi rahatlatıcı ve yeniden var edici bir biçimde kullanılmaktadır. Bireyler, önemli gün ve bayramlarda ya da tatillerde memleketlerine gelerek o aidiyetliğin verdiği güvenlik hissini yaşamakta, bu tutumları da kuşaktan kuşağa aktarmayı amaçlamaktadırlar. Böylece yaşadıkları kentlerde kendilerini tanımladıkları çifte kimliklerle belleklerini sürdürmeye çalışmaktadırlar. Yemek kültürünün gündelik hayattaki izdüşümlerinin bir uzantısı olarak Karabük örneğinde Hıdırellez etkinliklerinde ortaya çıkan yemek-kimlik ilişkiselliği dikkat çekici bulunmuştur. Bu bağlamda çalışmayı tamamlayıcı bir özgünlük olması ve farklı bir yol izleği olması bakımından İstanbul'a göç etmiş ve Hıdırellez zamanında Karabük'e gelen 8 katılımcı ile yemek kültürü ve şehir kimliğinin özgünlük ve aidiyet bağlamında hikayesinin izi sürülmüştür.

Katılımcılara yerleştikleri şehirlerde aidiyetliklerini tanımlama biçimleri sorulduğunda kendilerini "Karabüklü" olarak tanımlamaya ayrıcalıklı bir anlam yükledikleri görülmüştür. Hıdırellezle geliştirdikleri aidiyetliklere yükledikleri 
anlamları şu şekilde aktarmışlardır. Katılımcıların "Hıdırellez'e niçin katıllyorsunuz?" sorusuna verdikleri yanıtlarda "Karabüklü olma ayrıcalı̆̆ını yaşama" (M2, M5, M8), H1dırellez'i "memleket ziyareti için geçerli bir sebep" olarak görme (M3, M7), "büyükssehirde memleket aidiyetliğini sürdürebilmenin kültürel boyutu” (M6), "çocuklara Karabüklü olmayı hatırlatabilmek için sembolik anlam yüklenen bir ritüel" (M1) ve "farklı şehirlerde yaşayanlarla ortak bir mekân olarak memlekette buluşma" (M4) ifadeleri dikkat çekmiştir. Burada hıdırellezin yemek kültürüyle ilişkili tarafı kuşkusuz bir bahar festivali olarak yemeklerle ve yemek etrafında gerçekleşen ritüellerin bir toplamı olmasıdır. Karabük'te Hıdırellez etkinliklerinin en temel ritüeli kurban kesmek ve yemeklerin pişirilmesidir. Etkinlik, bir mezarlıkta veya yerli halk tarafindan kutsallık atfedilen bir türbe etrafında gerçekleştirilmektedir. Kurbanın sabahtan kesilmesi peşi sıra büyük kazanlarda etler pişirilmekte, yan yana kurulmuş birkaç kazanda ise pilav ve diğer yemekler pişirilmektedir. Köyün kadın ve erkeklerinin birlikte hazırlık yaptı̆̆ organizasyonda, hazırlanan yemekler öğlen namazı sonras1 yenmektedir. Burada karşılıklı etkileşimlerin olması ve ritüellerde çocukların yer alması altı çizilmesi gereken bir toplumsal bağlamdır. Burada etkileşimlerin belirgin özelliği ritüel boyunca sohbetlerin olması ve bu sohbetlerde temaların kimlikle ilişkili yönlerinin olmasıdır. Sohbet konularında ilk tema köyün geçmişine dairdir. Geçmişten bugüne değişen gelenekler, ilişkiler, kaybolan kültür ve bugünün kuşaklararası farklılıklarına dair birçok söylem üretilmektedir. Bu söylemler, özellikle şehir dışından gelen katılımcıların yoğun olarak katıldıkları bir etkileşim ağı oluşturmaktadır. Katılımcılar, birlikte getirdikleri çocuklarını da bu sohbetlerin merkezine yerleştirmektedirler. Hıdırellez de ritüelleri yaşatma çabası, aynı zamanda katılımcıların köyün tarihini ve köyle birlikte yaşatmaya çalıştıkları bellekle Karabüklü olmayı sürdürmeyi yansıtmaktadır. Böylece katılımcılar, Hıdırellez'de Karabük'e gelmiş olmalarının aynı zamanda memleketlerine gelmek ve buradaki toplulukla özlemlerini gidermek ve Karabüklü olmayı sürdürmek şeklinde ortak söylemler kullanmışlardır. Belleğin yenileyici ve kültürel kökleri hatırlatıcı yönünün açığa çıktı̆̆ı görüldüğünde, Hıdırellez'e bahar bayramı ötesinde anlamların yüklendiği görülmüsstür.

Katılımcıların Karabük'teki Hıdırellez ile kurdukları ilişkisellikte sorgulanan bir diğer bağlam "göçmen olarak yaşadıkları büyükşshirde değişimlerden korunma biçimi olarak yerelle gelişstirdikleri iliş̧kinin yorumlanması" üzerinden değerlendirilmişsir. Bununla ilişkili olarak katılımcılara "büyükşehirlerde kültürel kimliğinizi nasıl koruyorsunuz?" ve "geleneklerinizi yaşatırken yemek kültürünüz nerede durmaktadır?" soruları yöneltilmiştir. İlk soruya verilen yanıtlarda "aynı mahallelerde yaşamaya dikkat etme” (M3, M5, M8), "Karabüklülerle biraraya gelerek piknik ve benzeri etkinlikler yapma" (M8), "memlekete firsat buldukça gitme” (M1, M4), "dede ve ninenin de birlikte yaşadı̆̆ geniş aile şeklinde ilişkileri sürdürme” (M6), "fotoğraf albümleri" (M2) ve "yöresel ürünler, klyafetler ve eşyaları kullanma" (M7) temaları ön plana çıkmıştır. Katııımıların yanıtlarından hareket edildiğinde iki nokta dikkat 
çekmektedir. Bunlardan ilki göçmenin geldiği memleketiyle kurduğu ilişki türü bir çeşit kimlik koruma biçimidir. Kimliği koruma güdüsü, "nerelisin?" sorusuyla muhatap olan göçmenin belleğini ve yaşanmışlarını organize etme biçimi olarak kendini dışa vurmaktadır. Dikkat çeken diğer bir nokta ise bir arada olmak için mutlaka bir yemek etkinliğinin düzenlenmesidir. "Dügüun, kına gecesi, mevlit, doğum ve piknik bu tür etkinliklerin detaylandırlması" (M1, M5) olarak göze çarpmıştır. Yöresel ürünlerin kullanım biçimleri de Karabük ile özdeş yemekleri ve tarımsal ürünleri kapsamaktadır. Katılımcılar şehir hayatları süresince yöresel mutfaklarından kopamamaktadır. Yöresel mutfağın şehirde yaşatılmasındaki temel kayg1 yemeklere kültürel kimliğin yaşatılmasında sembolik anlam yüklemeleridir. Memlekette kurulan ilişkide katılımcılar hem ev ekonomisine katkı hem de memleketleriyle bağların sürdürülmesinin araçsal bir formu olarak Karabük dönüşlerinde yöresel ürünleri evlerine getirmektedirler. Gidemedikleri zamanlarda ise aynı ürünleri (sıklıkla yiyecek, içecek ve gıda) "Karabük'te bulunan birincil derecede yakınlarl tarafindan kendilerine gönderildiklerini" (M5) ifade etmektedirler. Bu bağlamın, katmanlaşma yaklaşımında yöresel mutfağın alt kategorilerinde kullanılmış özgünleşme temasının kimlik alt başlığına ve aidiyet temasına karşl1ık geldiği düşünülmüştür.

Çalışmanın bu kısmında katılımcılara yöneltilen son soru ise "kuşaklararası bağları sürdürmede etkinliğe katılmaya nasll bir anlam yükledikleri" konusundaki tutumların sorgulanması bağlamında kurgulanmıştır. Bu kaygıyla katılımcılara yöneltilen "Hıdırellez'e yükledikleri anlam nedir?" sorusuna verilen yanıtlara bakıldığında dikkat çeken noktaları şu şekilde aktarmak mümkündür. Katılımcıların büyük bir çoğunluğu yemek yemek ve kültürel bir ritüelden öte "göçle dağılmış Karabüklüleri birleştirici pratik” (M1, M4, M5, M8) şeklinde betimlenmiştir. Böylece şehir dışından gelen göçmenlerin, köylerinde ve mahallerinde yapılan etkinliklere katılımları onların kimliklerini tazeleyici birer çerçeveleyici role bürünmektedir. Bireylerin hazırda olan topluluğa katılmaları kültürün yaşatılması için yeterli görülmüştür. Katılımcıların görmeye ve pratiğin içerisinde yer almaya da ayrıca bir değer yükledikleri, bu değer yüklemeyi de özellikle çocukları için yaptıkları görülmüştür. Bu bağlamda katılımcılardan birisi "büyü̈ssehirde yaşarken çocuklara Karabüklü olmayı hissettirmek gerekiyor. Bunun için memleketi ve Karabüklüleri görmenin önemli olduğunu” (M2) ifade ettiği görülmüştür. Pratiğin içerisinde yer almaya da "çocuğun belleğinde memleketin kalıcılığının sağlanması kaygısıyla yapıldı̆̆g”" (M7) anlamı yüklenmiştir. $\mathrm{Bu}$ kalıcılığı sağlayan şey ise ritüelin etrafında paylaşımların ve etkileşimlerinin olmasıdır. Hıdırellez'de aktif olarak yer alan ve organizasyonu yürüten yaşlı kuşakla muhatap olunmaya ise iki farklı anlam yüklenmiştir. Bunlardan ilki "kültürün taşıyıcısı olarak gelenekleri ve görenekleri yaşlılardan deneyimleyerek öğrenmelerinin sağlanması" (M6), diğeri ise "kendileri eğer bir gün ölürlerse onlardan sonra da çocuklarının tıpkı bizim atalarımızdan öğrendiğimiz gibi bu ritüelleri sürdürmelerini sağlamak" (M3) şeklinde ifade edilmiştir. Katılımcıların aktarımlardan hareket 
edildiğinde göç ve ötesinin, kültürü yaygınlaştırıcı etkisi olması bakımından dikkat çekicidir. Göçlerle yeni yaşam alanları oluşturan topluluklar, geldikleri yerlerde kültürlerini yaşatırken, memleketleriyle olan bağlarını da çift yönlü devam ettirmektedir. Bir yönüyle kentte yaşattıkları pratiklerle değişime direnirken, diğer taraftan memleketleriyle sürdürdükleri bağlarla da çocukları üzerinden kuşaklararası bağlantıları sağlamaya çalışmaktadırlar. Hıdırellez'in kültürel kimlik göstergesi olarak kabulü ise iki sebepten ötürüdür. İlki Karabük’te yaşayanlar için geçmişten bugüne kuşaklararası bağlantıyı sağlayan en temel göstergelerden birisi Hıdırellez'dir. Sanayileşmenin kültürü melezleştirmesi veya anonimleştirmesi dikkate alındığında Hıdırellez'in Karabük'te sürdürülüyor olması bu bakımdan kültürel kimlik bahsiyle dikkat çekici bulunmuştur. Diğeri ise Hıdırellez etkinlikleri için şehir dışından gelen ailelerin varlığıdır. Bunlar hem çocukları için belleğin sürdürülmesi sürecini yönetmeye çalışmakta hem de büyükşehirde yaşatamadıkları kültürlerini burada sürdürmeyi denemektedirler.

\section{Fastfoodlaşan Yöresel Mutfak}

Karabük'te fastfoodlaşan mutfağın tartışılması, katmanlaşma yaklaşımını tamamlayıcı bir içeriğe sahiptir. Yöresel ve bölgesel mutfak tek başına düşünüldüğünde küreselleşmenin yemek kültürü üzerindeki izlerini sürmek eksik kalmaktadır. $\mathrm{Bu}$ eksikliğin giderilmesi ve küreselleşmenin melez mutfakların ortaya çıkışına kaynaklık etmesine yapılmak istenen vurgu katmanlaşma yaklaşımında "fastfood mutfă̆gl" üçüncü bir ana tema olarak almayı zorunlu kılmıştır. Böylece küreselleşmenin yöresel hem de bölgesel mutfak üzerine kurduğu dönüştürücü baskının anlaşılması kolaylaşacaktır. Öncelikle sahada gözlemlenmiş olan temel noktaların başında "fiziksel olarak mekânin organizasyonu yemek üzerinden nasıl gerçekleşmektedir?" sorusuna verilen yanıtlar gelmektedir. Diğer gözlem hedefleri ise "mekânların yemeği nasıl organize ettikleri", "menülerin nasıl tasarlandiğı", "kafeler, fastfood mekânlarl ve esnaf lokantalarının birbirlerinden ayrıștlkları ve birleştikleri temel noktaların tespit edilmesi" ve "geleneksel tutumların nasıl değiştiği " olmuştur.

2007 yılında Karabük Üniversitesi'nin kurulmasıla birlikte Karabük’te yeni bir değişim başladı. 1937 yılında Demir Çelik Fabrikaları'nın kurulmasıyla başlayan değişim, fabrikanın 1994 yılında özelleştirilmesiyle yeni bir boyut kazandı. 1937 yılından 1980'li yılların sonuna kadar düzenli göç alan Karabük, dışarıya göç vermeye başladı. 2007 yılında ise şehir yeni bir dinamik kazandı ve dışarıdan yeniden göç almaya başladı. Öğrenci sayısının da düzenli artmasıyla birlikte şehirdeki öğrenci sayısı gittikçe yükselmiştir (Sağır ve İnci, 2013). Artan öğrenci sayısı Karabük’te mekânsal bir dönüşümün yaşanmasına neden oldu. Bu mekânsal dönüşümler içerisinde evler, yurtlar dahil birçok binanın yapılmasını, yerlilerin üniversiteye yakın mahalleleri öğrencilere bırakıp daha dışarıya doğru taşınmalarını, müstakil bahçeli evlerin yerine 
apartmanların yapılmasını, tarlaların inşaata açılarak büyük konutların yapılmasını içermektedir. Ancak burada değişimin en önemli dinamiklerinden birisi yöresel mutfağın, öğrencilerin gelişiyle birlikte daha genel bir mutfak görünümü kazanmaya başlaması olmuştur. Buradaki kasit, öğrencilerin fastfood mutfağa dönük talepleridir. Öğrenciler için fastfood mutfak, zaman kazandırıcı, kolay ulaşılabilen ve ekonomik (ucuz) mutfaktır. Ritzer 'in (2019) "fastfoodla saniyeler içerisinde bitirilen bir pratiğe dönüşen yemek" aynı zamanda öğrenciler için ihtiyacın ucuz giderilme aracıdır. Öğrencilerin fastfood mutfağa yönelmesi, ekonomik harcama güçleriyle doğru orantılıdır. Dönerci, kebapçı, kafe, tatlıcı ve market sayısındaki artı̧̧ mekânın fiziksel dönüşümünden ziyade yöresel mutfağın ve beslenme alışkanlıklarındaki değişimde öncü araçlar olmuştur.

Bu mekânsal organizasyon, aynı zamanda Ritzer'in McDonaldlaşmasına (2019) da uygundur. Türkiye'de birç̧ok yerde olduğu gibi Hatay döner ya da Mersin tantuni, bunların dışında özellikle büyükşehirlerde hizmet sunan fastfood markalarının Karabük’te şube açmaya başlamaları, tatlıcıların artışı, markalaşmış kahve mekânlarına öykünme ile organize edilen kafeler, Karabük'ün dönüşümünün temel ayak izleri olmuştur. Esnaf lokantalarının değişimi de sürecin bir parçasıdır. Bu bağlamda yerelin küresel dönüşüme ayak uydurması somut olarak esnaf lokantaları üzerinden gerçekleşmiştir. Esnaf, sürece ayak uydururken, yöresel yemekleri sunmaya devam ederken bunların yanında fastfood mutfağa ait pizza, döner ve hamburger gibi ekonomik ve hızlı tüketilen yemekleri de eklemeye başlamıştır. Böylece ilkin esnaf menüsünün küreselleşmesi, arkasından ise menünün mekânı organize etmesi deneyimlenmiş̧tir. Hall' in (2007) küreselleşmenin hem kültürel farklılıklar sayesinde yaşadığına yaptığı vurgu hem de yerel kimlik olmadan var olmayacağına dair çıkarımı, menünün dönüşümüne uygun bir örnektir. Bu bağlam Robertson'un (1999) yerel kültürü gözeten küreselleşme tanımlamasına uygundur. Deneyim ise Shugart'ın (2015) küreselleşmiş popüler kültür içerisinde ötekiyle güvenli bir şekilde etkileşimi de içerir. Kuşkusuz küresel markaların internet üzerinden müşterilere sipariş ulaştırma yöntemleri, esnaf lokantaları tarafindan da taklit edilmeye başlanmıştır. İnternetteki yemek sipariş sitelerine üye olmaya başlayan esnaf, klasiğin ötesine geçerek postmodernleşmeye başlamıştır. Bütün bu değişimlerin dinamiğinde esnafin öğrencilere ayak uydurmaya çalışması olmuştur. Farklı bölgelerden gelmelerine rağmen öğrencileri aynı paydada birleştiren temel gösterge fastfood mutfak olmuştur. Tek tip, içeriği belli ve belirsizliği olmayan mutfağın beslenme alışkanlıkları farklı bireyler tarafından tercih edilmesi riskin en aza indiği bir süreç olarak kendisini inşa etmiştir. Esnaf lokantasında yöresel, bölgesel ve fastfood mutfağın üçlü bir şekilde sunulma biçimi, süpermarketteki gibi farklı statülerdeki insanların girdikleri dükkânda istedikleri yemekleri yemelerinin önünü açtı. Bu aynı zamanda yemek kültürü üzerinden belli bir esnekliğin oluşmasına kaynaklık etmiştir. Kuşkusuz burada mutfağın fastfoodlaşmasını kültürel bir gösterge olarak değerlendirmek mümkün değildir. Ancak mutfağın dönüşümünün anlaşılması, küreselleşmenin beslenme alışkanlıklarını değiştirmesi açısından, yine benzer şekilde geleneksel kavramlaştırmaların değişmesini gösterir önemli 
örnek olarak göze çarpmaktadır.

Mekânları sınıflandırırken içecek mekânlarının da ayrıca dikkat çektiği görülür. Kafelerin hızlı bir şekilde yaygınlaştığını ve ihtiyaçlara göre sürekli yenilendiğini değiştiğini ve şekillendiğini görmek mümkündür. Mekânların sürekli yenileniyor olması mutfağa dinamiklik katmaktadır. Öğrencilerin ihtiyaçlar takip edilirken beklentileri öngörülmekte, kafeler içecek yanında yemek yeme seçenekleri de sunmaktadır. Öğrenciye müşteri olarak bakan kafelerin bir süre sonra menülerine fastfoodu ve yöresel mutfağa ait yemekleri de ekliyor olmaları, mutfağın yeni bir melezleşmeyle karşılaştığını göstermektedir. Kuşkusuz bu durum fastfoodlaşmanın hızlıca dönüş̧ürdüğü bir kültüre atıf yapmaktadır. Burada fastfodlaşmanın vurgulanması, daha önce bahsi geçtiği gibi McDonaldlaşmanın da kendisini göstergelere dökmektedir. Mekânlar McDonaldlaşma tezine uygun bir şekilde organize edilmektedir. Dolayısıyla fastfoodlaşan mutfak, hızlı tüketim, kolay erişim ve melez bir mutfak olarak karşımıza çıkmaktadır. Burada yemek geleneksel formların dışına çıkmakta ve kültürel anlamını kaybetmektedir. Yemek ilkçağ insanlarındaki gibi temel ihtiyacın karşılanması şekline dönüşmektedir. Yemek tüketime dönüşürken "hap" alır gibi hızlıca yutulan bir pratiğe dönüşmekte ve süreç olma özelliğini yitirmektedir. Kafeler ise içecek mekânı anlamının dışına çıkarak göstergelere, statülere ve sembollere dönüşür. Böylece mekân, içecek etrafında oluşan hiyerarşik bir sistemin göstergesi olmayı meşrulaştırır (Akarçay, 2012; Akarçay, 2016). Sosyal medyadaki yer bildirimlerinde özellikle kafeler olarak tercih edilmesi bu bağlamda önemli bir göstergedir ve içecek mekânlarının statü göstergesine dönüştüğünün besleyici kaynağıdır. Bu bağlam, dışarıda yemek yemeyle ilişkili yapılan sınıflandırmalarda "haz", "statü" ve "prestij" amaçlarına denk gelmektedir (Özdemir, 2010, s. 221; Akarçay ve Suğur, 2015, s. 6-7). Bu bağlamda üniversite mahallesinde mutfak, yiyecek, içecek, gıda ve diğer biçimleriyle öğrenciye hitap eden bir mutfaktır. Öğrencilerin ihtiyaçlarına göre şekillenmektedir. Temel özelliği kimlik ve kültür olmaktan ziyade tamamen "beslenme formu olmast ve insanlara zamandan tasarruf kazandırmasıdır" (Akarçay ve Suğur, 2015, s. 24). Burada ekonomik göstergeler tartışmaya eklemlenmektedir. Öğrencilerin geliri ve harcama alışkanlıkları düşünüldüğünde ilk tavizlerinin yemek olduğu görülmektedir. Fastfood mutfak, topluluğun tarihle bağını koparttığından kültürel belleği unutturucu bir işleve sahiptir. Bu bağlamda Cook ve Crang' in (1996) bölgesel mutfak için ifade ettiği “tarihsel yemek gelenekleriyle pek az ilişki” (akt. Ichijo ve Ranta, 2018) nitelemesi fastfood mutfak için da kullanışlı durmaktadır. Böylece fastfood mutfak tek tipleşmenin, standartlaşmanın ve bir süre sonra da sağlık risklerinin bir uzantısı olmaktadır. Ancak şu noktaya da dikkat çekmek gerekir. Fastfood mutfak aynı zamanda teşhir ve gösteri toplumunun bir uzantısı olarak okunabilir. Burada çok güçlü olan yemek külttürünün de teslim olmadığını direnç gösterdiğini ancak ticari bir nesneye dönüşerek değiştiğini ileri sürmek mümkündür. Yemeğin materyalleşmesinin de buna eşlik ettiği görülmektedir. 


\section{Sonuç}

$\mathrm{Bu}$ araştırmanın niçin yapıldığı sorusuna verilecek yanıt, gıdayla ve beslenmeyle ilgili tartışmaların yükseldiği günümüzde daha anlamlı durmaktadır. Yükseliş, Korona virüs sürecinde \#evdekal'manın insanların yemekle ilgili pratiklerini değiştirmesiyle doğrudan ilişkilidir. Bu tartışmalara gıdanın geleceği, yemek mekânlarının yeniden organizasyonu, AVM'lerin kapanmasıyla fastfood yeme-içmenin durması, ekmek pişirmenin eve taşınması ve balkon/bahçelerin sebze ekip biçmeye dönüşmesi gibi birçok alt başlık eşlik etmektedir. Beslenmenin temel insani ihtiyaç olması yemek ve gıda ile ilgili gündemin sürekli canlı kalacağının temel besleyicisidir. Aslında pandemi sürecinde yemeğin önemli bir gündelik hayat pratiği olduğunu deneyimlendi. $\mathrm{Bu}$ deneyimin anlaşılması, topluluğa yemeğin sosyolojik kökenlerini hatırlattı. Ancak yemek uzun bir süredir "tüketim endüstrisi içerisinde alınıp satılan bir materyal" olarak ön planda olmuştur. Materyalleşme, bir nesneleşme halidir ve toplumsal bir olgunun tarihsel ve kültürel köklerini kaybedişini anlatmaktadır. Tüketim toplumu içerisinde piyasa kültürüne teslim olmayı ve içerisine aldığı her şeyi ticari bir tüketim metasına dönüştürmesini betimlemektedir. Bu bağlam, Ritzer'in (2019) vurguladığg bağlamıyla McDonaldlaşmanın yemek kültürü üzerindeki etkisini açıklamaktadır. Materyalleşme küresel dünyanın ulusal, bölgesel ve yöresel mutfak üzerine kurduğu baskının kimlik, kültür ve aidiyet tartışmalarına uzanmaktadır.

Katmanlaşma yaklaşımı çalışma boyunca mutfakla ilgili yaşanan her türlü değişmeyi anlamak ve anlamlandırmak için yeni bir yaklaşım olarak önerildi. Yaklaşım, yemek kültürünün ait olduğu topluluk pratiklerini yöresel, bölgesel ve fastfood mutfak şeklinde üç temel kategoriye ayrıldı. Aralarındaki ayrışmalar keskin olmamakla birlikte yöresel mutfak bir ülkenin içindeki bölgeye has yemek alışkanlıklarını; bölgesel mutfak ise tarihsel yemek gelenekleriyle pek az ilişkinin olduğu yemek pratiklerinin modern yorumu ve Fast Food mutfak ise küreselleşmenin yemek pratikleri üzerine zaman, mekân ve ilişkiler açısından yaptığı değişimleri ifade etmek için kullanıldı. Böylece katmanlar olarak sınıflandırılan yöresel mutfak özgünlüğü, bölgesel mutfak ulusal bir boyutu ve Fast Food mutfak ise küresel olanı temsil etmektedir. Kavramsal organizasyonun inşası (şekil 1), materyalleşme alt okumasıyla ilişkili bir şekilde topluluğun kültürel kökleriyle ilişkisinin nasıl bozulduğunu ve birbirinden nasıl bağımsızlaştığını ortaya koymak için tercih edildi. Bu tercihlerin sınıflandırılmasında her bir katmanın kendine özgü görünümleri etkili oldu. Katmanlaşma yaklaşımında her üç deneyimin ortak noktası kültür ve kimlik üzerinden mutfağın kendine ait taraflarının öne çıkışı olmaktadır. Bu bağlamda aidiyet, millilik, küresellik, bellek, yerellik mutfakların ortak deneyimlerini yansıtmaktadır. Katmanlaşma yaklaşımının çalışma boyunca "katmanlar arasında pastaya benzer şekilde tat geçişlerini" vurguladığı bağlam, ortak deneyim alanıdır. Katılımcıların aktarımlarında zaman zaman yemekle kurulan ilişkide ortaya çıkan iç içe geçişler, bu noktayı meşrulaştırmaktadır. 
Kuşkusuz bu deneyimin makro ve mikro boyutta gerçekleşmesi topluluğun kendisini ilişkilendirdiği coğrafi alanla ya da mekândaki konumuyla ilişkilidir. Bu boyutların katmanlar arasında deneyimlenmesi ise paralel bağlantılar yoluyla gerçekleşir. Çalışmada "göçmen" bu nedenle önemsenmiştir. Çünkü göçmen özgün mutfağını korumaya çalışırken yaşadığı topluluğa da ayak uydurarak yeni sentez pratikler üretir. Çalışmada yöresel olan, tarihsel kökleriyle özgünlügünü korumaya çalışırken küreselleşmenin karşısında anonimleşmeyi nasıl deneyimlendiğini ortaya koymak için kullanıld1. Fast Food ise standartlaşma, tek tipleşme ve rasyonalizasyon süreçlerinin dönüştürdüğü pratiklerde özgün olanın nasıl küreselleştiğini ve küresel olanın da nasıl yerelleştiğini betimlemek için kullanıldı.

Karabük özelinde katmanlaşma yaklaşımının çerçevelendiren önemli noktaları şu şekilde tartışmak mümkündür. Safranbolu özgün ve yöresel mutfak iddiasını tarihsel ve kültürel geçmişiyle temellendirmektedir. Ancak çalışma boyunca Safranbolu'da geleneksel yemek pratiklerinin kaybolduğu tespit edilmiştir. Yöresel adlandırmayla açılan mekânlarda özgünlükten ziyade turistlerin sıklıla tercih ettikleri menüleri yapılandırmaktadır. Türkiye'de turistik bölgelerdeki hediyelik eşyaların birbirine benzediği Pazar kültürüne atıfla, McÇinlileşme, yemeklerin de anonimleşerek ve küreselleşerek kültürel özgünlüğünü kaybettiği görülmüştür. Çalışmada bölgesel mutfağın sentez bir mutfak kültürü olduğu tespit edilmiştir. Yöreselin genişlemesi, özgünlüklerin yeni bir forma bürünmesi ya da farklı mutfaklarla birlikte yaşama özelliği bu katmanın çalışmada ortaya koyulmuş tarafıdır. Çalışmada fastfood mutfak katmanının mekânı ve geleneksel mutfağı parçaladığı ve toplumsal ilişkileri dönüştürdüğü bir bağlamı ortaya çıkardığı tespit edilmiştir. Ayrıca Karabük Üniversitesi'ne farklı ülkelerinden gelen yabancı uyruklu öğrenciler, küreselleşmeyi Karabük'te farklı bir boyuta taşımaktadır. Mekânlar üzerinde artan baskı, göçmen öğrencilere dönük yemek mekânlarının açılmasına neden olmuştur. Böylece farklı ulusal mutfakların Karabük'e girişi başlamıştır ki bu Karabük'ün ilk defa deneyimlediği bir süreçtir. Böylece katmanlaşmanın gittikçe daha alt boyutlara bölünmesi gerekliğini ortaya koymuştur. Her farklı deneyimin yeni bir katman ortaya çıkardığg ve diğer katmanlarla doğrudan ilişkisinin olduğu bir gündelik hayat fotoğrafın çıkması, katmanlaşma yaklaşımının özgünlüğü temsil etmesi bakımından oldukça önemlidir.

\section{Katılımcilar}

Safranbolu Çarşıı Katılımcıları: K1. Erkek, Esnaf (Yöresel Mutfak); K2. Erkek, Esnaf (Kafe); K3. Kadın, Esnaf (Kafe); K4. Erkek, Esnaf (Lokum); K5. Kadın, Esnaf (Lokum); K6. Kadın, Esnaf (Kafe); K7. Erkek, Esnaf (Lokum); K8. Erkek, Esnaf (Yöresel Mutfak); K9. Erkek, Esnaf (Yöresel Mutfak); K10. Kadın, Esnaf (Yöresel Mutfak); K11.Kadın, Esnaf (Yöresel Mufak); K12.Kadın, Esnaf(Konak İşletmecisi).

Karabük Mutfağı Katılımeıları : T1.Erkek, Esnaf (Restoran İşletmecisi); 
T2. Kadın, Memur (18 yıldır Karabük'te yaşıyor); T3.Kadın, Esnaf (Restoran Çalışanı); T4.Kadın, Öğretmen, (9 yıldır Karabük’te yaşıyor); T5.Erkek, Esnaf (Restoran İşletmecisi); T6.Kadın, Öğretim Üyesi (5 yıldır Karabük’te yaşıyor); T7.Erkek, Öğretim Üyesi (13 yıldır Karabük’te yaşıyor); T8.Erkek, Esnaf (Esnaf Lokanta İşletmecisi).

Göç Mutfağı Katılımcıları: M1. Kadın, 41, (İstanbul'da yaşıyor); M2. Kadın, 25, (İstanbul'da yaşıyor); M3. Erkek 47, (İstanbul'da yaşıyor); M4.Erkek, 70, (Safranbolu'da yaşıyor); M5. Kadın, 58, (Karabük’te yaşıyor); M6.Erkek, 64, (Karabük’te yaşıyor); M7.Kadın, 34, (İstanbul'da yaşıyor); M8.Kadın, 49, (İstanbul'da yaşıyor).

Hakem Değerlendirmesi: Dış bağımsız.

Çıkar Çatışması: Yazar çıkar çatışması bildirmemiştir.

Finansal Destek: Yazar bu çalışma için finansal destek almadığını beyan etmiştir.

Peer-review: Externally peer-reviewed.

Conflict of Interest: The author declares no potential conflicts of interest with respect to the research, authorship, and/or publication of this article.

Grant Support: The author received no financial support for the research, authorship, and/or publication of this article.

\section{Kaynakça/References}

Akarçay, E. (2012). Kah kahvehane kah cafe: Küreselleşen Eskişehir'de kahve tüketimi üzerine kuramsal bir giriş [Özel Sayı]. İletişim, 2, 181-202.

Akarçay, E. (2016). Beslencenin sosyolojisi. Phoenix Yayınları.

Akarçay, E., ve Suğur, N. (2015). Dışarıda yemek: Eskişehir'de yeni orta sınıfın fast-food yeme içme örüntüleri. Sosyoloji Araştırmaları Dergisi, 18(1), 1-29.

Altınöz, M. Ö. (2019). Safranbolu'da kültüre miras, müze kent alımlaması ve kentin folklorik sürdürülebilirliği. Insan ve Toplum Bilimleri Araştırmaları Dergisi, 8(2), 1214-1225.

Altundağ, Ö. Ö. (2018). Turistlere sunulan yöresel yemeklerin makro ve mikrobesin öğesi içeriğinin sağlık boyutu: Safranbolu ilçesi örneği. Safran Kültür ve Turizm Araştırmaları Dergisi, 1(1), 16-28.

Anderson, K. N. (1993). The international dictionary of food and nutrition. Wiley.

Assmann, J. (2001). Kültürel bellek (A. Tekin, Çev.). Ayrıntı Yayınları.

Barthes, R. (1979). Towards a psycho-sociology of contemporary food consumption.In R. Forster \& O. Ramuin, (Eds.), Food and drink in history (pp. 35-58). The Johns Hopkins University Press.

Bauman, Z. (2017). Cemaatler/Güvenli olmayan bir dünyada güvenlik arayışı (N. Soysal, Çev.). Say Yayınları.

Bauman, Z. (2019). Akışkan modernite (S. O. Çavuş, çev.). Can Yayınları.

Beardsworth, A., ve Keil, T. (2012). Yemek sosyolojisi: Yemek ve toplum çalışmasına davet (A. Dede, çev.). Phoenix Yayınevi.

Beck, U. (2014). Risk toplumu - Başka bir modernliğe doğru (K. Özdoğan ve B. Doğan, çev.). İthaki Yayınları.

Belge, M. (2016). Tarih boyunca yemek. İletişim Yayınları. 
Bennett, J. W. (1943). Food and social status in a rural society. American Sociology Review, 8(5), 561-569.

Beşirli, H. (2010). Yemek, kültür ve kimlik. Milli Folklor, 22(87), 159-169.

Beşirli, H. (2011). Türk kültüründe güç, iktidar, itaat ve sadakatin yemek sembolizmi esasında değerlendirilmesi. Türk Kültürü ve Hacı Bektaşi Veli Araştırma Dergisi, 58, 139-152.

Beşirli, H. (2017). Yemek sosyolojisi yiyeceklere ve mutfăga sosyolojik bakış. Phoenix Yayınları.

Canbolat, İ. (2017). Safranbolu şehir yemekleri. https://www.academia.edu/3538529 2/Safranbolu_ Yemekleri__S\%C3\%B6zl\%C3\%BC_Tarih_\%C3\%87al\%C4\%B1\%C5\%9Fmas \%C4\%B1.docx

Canbolat, İ. (2019). Safranbolu'da şehir yemekleri. https://www.academia.edu/4079 6635/\%C3\%87ar\%C5\%9F\%C4\%B1da_Safranbolu_Yeme-\%C4\%B0\%C3\%A7me_\%C3\%9C zerine

Carolan, M. (2012). The sociology of food and agriculture. Routledge.

Connerton, P. (1999). Toplumlar nasıl anımsar (A. Şenel, Çev.). Ayrıntı Yayınları.

Counihan, C. M., \& Esterik, V.P. (2013). Food and culture. Routledge.

Counihan, C. M., \& Kaplan, S. L. (1998). Food and gender identity and power. Routledge.

Cronin, M. (2014). Cooking the books: Translation, food and migration. Comparative Critical Studies, $11(2-3), 337-354$.

Demirer, H. R. (2010). Yöresel ürün ve coğrafi işaretler; Fransa ve Türkiye üzerine bir inceleme (Doktora Tezi). Akdeniz Üniversitesi Sosyal Bilimler Enstitüsü, Antalya.

Depeli, G. (2010). Görsellik ve kültürel bellek ilişkisi: Göçmenin evi. Kültür ve İletişim, 13(2), 9-39.

Fiedlhouse, P. (1995). Food and nutrition customs and culture. Springer.

Fischler, C. (1988). Food, self and identity. Social Science Information, 27, 275-293.

French, S. A., Harnack, L., \& Jeffery, R. W. (2000). Fast food restaurant use among women in the Pound of Prevention study: dietary, behavioral and demographic correlates. International Journal of Obesity, 24(10), 1353-1359.

Gellner, E. (1994). Encounters with nationalism. Wiley-Blackwell.

Giddens, A. (2019). Modernite ve bireysel kimlik/geç modern çağda benlik ve toplum (Ü. Tatlıcan, Çev.). Say Yayınları.

Goody, J. (2013). Yemek, mutfak, sinıf (M. G. Güran, Çev.). Pinhan Yayıncılık.

Gültekin, H. (2019). Yemek sosyolojisi bağlamında üniversite ögrencilerinin yemek yeme alı̧̧kanlıklarının değerlendirilmesi: Cumhuriyet Üniversitesi örneği (Yüksek Lisans Tezi). Cumhuriyet Üniversitesi Sosyal Bilimler Enstitüsü Sosyoloji Ana Bilim Dalı, Sivas.

Halbwachs, M. (2017). Kolektif hafiza (B. Barış, Çev.). Heretik Yayınları.

Hall, S. (2007). Yerel ve küresel: Küreselleşme ve etniklik. A. D.King (Ed.), Kültür, küreselleşme ve dünya sistemi içinde. Bilim ve Sanat Yayınları.

Ichijo, A., ve Ranta, R. (2018). Yemek ve ulusal kimlik. (E. Ataseven, Çev.). Ayrıntı Yayınları.

Inness, S. A. (2001). Kitchen culture in America. University of Pennsylvania Press.

Jayasanker, L. (2020). Sameness in diversity food and globalization in modern America. University of California Press.

Karaca, O., B. (2016). Geleneksel peynirlerimizin gastronomi turizmindeki önemi. Journal of Tourism and Gastronomy Studies, 4(2), 17-39.

Kütükçüoğlu, M. (2010). Türkiye'nin ilk ağır sanayi kenti Karabük (Milli Şef döneminde). Karabük Valiliği Yayınları. 
Mak, A. , Eves, A., \& Lumbers, M. (2012). Globalisation and food consumption in tourism. Annals of Tourism Research, 39(1), 171-196.

McBride, A. E. (2005). Have your Coke and eat it too: What cooking with Coca-Cola says about cultural imperialism. Gastronomica, 5(1), 80-87.

Merdol, T. K. (2001). Kahvaltının önemi ve kahvaltı örüntümüz. K. Toygar (Ed.), Türk mutfak kültürü üzerine araştırmalar içinde (K. Toyga, Haz.). Türk Halk Kültürünü Araştırma ve Tanıtma Vakfı

Murcott, A. (2019). Introducing the sociology of food \& eating. Bloomsbury Academic.

Özdemir, B. (2010). Dışarıda yemek yeme olgusu: Kuramsal bir model önerisi. Anatolia: Turizm Araştırmaları Dergisi, 21(2), 218-232.

Ritzer, G. (2011). Küresel dünya (M. Pekdemir, Çev.). Ayrıntı Yayınları.

Ritzer, G. (2019). Toplumun McDonaldlaştırılması (Ş. S. Kaya, Çev.). Ayrıntı Yayınları.

Robertson, R. (1999). Küreselleşme: Toplum kuramı ve küresel (Ü. H. Yolsal, Çev.). Bilim ve Sanat Yayınlar1.

Sağır, A. (2012). Bir yemek sosyolojisi denemesi örneği olarak Tokat mutfağı. Turkish Studies, 7(4), 2675-2695.

Sağır, A. (2016a). Ölüm sosyolojisi bağlamında yemek, cenaze ve ölümün sofra pratikleri üzerine. Türkiye Sosyal Araştırmalar Dergisi, 20(1), 271-298.

Sağır, A. (2016b). İktisadi hayatın değişimi ve kayıp mesleki kodlar üzerine sosyolojik bir çözümleme: Zonguldak/Bartı/Karabük örneği. The Journal of Academic Social Science Studies, 48, 27-45.

Sağır, A., ve Canyaz, M. (2017). Sanayileşmenin toplumsal yansımaları: Safranbolu'da toplumsal değişme üzerine nitel bir araştırma. Turkish Studies, 12(3), 531-564.

Sağır, A., ve İnci, Ü. (2013). Karabük’te üniversite algısı: Karabük Üniversitesi örneği. Insan ve Toplum Bilimleri Araştırmaları Dergisi, 2(2), 49-81.

Schlosser, E. (2012). Fast food nation: The dark side of the all-american meal. Houghton Mifflin Company.

Shugart, H. A. (2008). Sumptuous texts: Consuming otherness in the food film genre. Critical Studies in Media Communication, 25(1), 68-90.

Stanley, J., \& Stanley, L. (2015). Food tourism: A practical marketing guide. Cabi.

Şahin, K. (2003). Geleneksel Antakya yemek kültürünün beslenme antropolojisi açısından incelenmesi (Yüksek Lisans Tezi). Mustafa Kemal Üniversitesi, Sosyal Bilimler Enstitüsü, Hatay.

Şengül, S., ve Türkay, O. (2016) Yöresel mutfak unsurlarının turizm destinasyonu seçimindeki rolü (Mudurnu Örneği). Uluslararası Yönetim İktisat ve İşletme Dergisi, 12(29), 63-87.

Toksöz, D., ve Aras, S. (2016). Turistlerin seyahat motivasyonlarında yöresel mutfağın rolü. Journal of Tourism and Gastronomy Studies, 4(1), 174-189.

Tuncel, M. (2000). Fast food (hızl yemek) sisteminin Türk mutfağına uyarlanması ve bir uygulama (Yüksek Lisans Tezi). Anadolu Üniversitesi Sosyal Bilimler Enstitüsü, Eskişehir.

Uğur, İ., Gökkaya, S., ve Acar, A. (2018). Yerli turistlerin destinasyon imajına ilişkin tekrar ziyaret etme niyetleri: Safranbolu üzerine bir çalışma. Safran Kültür ve Turizm Araştırmaları Dergisi, 1(1), 29-40.

Yenal, Z. N. (1996). Bir araştırma alanı olarak yeme-içmenin tarihi ve sosyolojisi. Toplum ve Bilim, $71,195-227$.

Yıldırım, A. ve Şimsek, H. (2011). Sosyal bilimlerde nitel araştırma yöntemleri. Seçkin Yayıncılık. 